\title{
Kekerasan Atas Nama Tuhan: Respons "Netizen" Indonesia
}

\author{
Fazlul Rahman \\ Peneliti Institute of Advanced Studies (IAS) Sekolah Pascasarjana UIN Jakarta \\ fazlulrahman85@gmail.com
}

\begin{abstract}
Violence in the name of God-terrorism attacks, violence toward minority even inter religious conflicts - has nowadays become a global issue. In Indonesia, there are at least 30 cases of "holy" violence committed in the last ten years. The demand to have such freedoms, as of expression, of speech, of getting access to information, could be seen as a process of an ongoing democracy. Internet, in this context, is one of the popular media to channel those ambitions of democracy. On the other hand, many Muslim extremists use this change and this media to channel their ideology of jihad. This article aimse to shed light on how the Indonesian netizen's (cyber community) response to those kind of radical Islamists messages. By using descriptive content analysis to the comments of the respective issue in Kaskus website, this paper sees the variety of the responses that would contribute to the prevention of violence in the name of religion and suggest some solutions.
\end{abstract}

\begin{abstract}
Abstrak
Kekerasan atas nama Agama-aksi terorisme, kekerasan terhadap minoritas, dan kasus konflik antar umat beragama - saat ini telah menjadi isu global. Di Indonesia, setidaknya terdapat 30 kasus "kekerasan suci" terjadi dalam kurun sepuluh tahun terakhir. Tuntutan untuk mendapatkan kebebasan (kebebasan berekspresi, kebebasan berbicara, kebebasan mendapatkan akses informasi) dalam hal ini dapat dilihat sebagai bentuk dari sebuah proses demokrasi yang masih terus berjalan. Internet, dalam konteks ini, adalah salah satu dari media yang paling banyak digunakan untuk menyalurkan hasrat demokrasi tersebut. Sementara itu, banyak dari kalangan ekstrimis Muslim yang memanfaatkan momen dan media tersebut untuk menyebarkan ideologi jihad mereka. Artikel ini secara spesifik akan menyoroti bagaimana netizen (masayarkat dunia maya) Indonesia merespons pesan-pesan berbau radikal tersebut dengan melakukan deskriptif konten analisis terhadap komentar-komentar mengenai isu terkait yang ada di website Kaskus. Artikel ini menunjukkan bahwa para netizen secara aktif merespons pesan-pesan kekerasan yang ada di dunia maya dengan
\end{abstract}


komentar-komentar yang kontributif untuk solusi pencegahan terjadinya kekerasan atas nama Tuhan.

Kata Kunci: kekerasan, agama, media, respons, dan Kaskus

\section{Pendahuluan}

Fenomena kekerasan berdalih agama di Indonesia telah menjadi momok yang sangat menakutkan akhir-akhir ini. Dalam sepuluh tahun terakhir, tidak kurang dari 30 kasus kekerasan atas nama agama terjadi di negeri ini. Tidak heran Indonesia saat ini telah menjadi sorotan dunia khususnya terkait masalah terorisme. Fenomena ini tentunya melibatkan banyak faktor yang saling berkaitan satu sama lain.

Di sisi lain, tingginya angka kekerasan yang terjadi ternyata berbanding lurus dengan fenomena kebangkitan agama yang salah satu buahnya adalah menguatnya gerakan yang mempunyai karakater fundamentalis yang dialami oleh semua agama dan terjadi hampir di setiap wilayah dunia. ${ }^{1}$ Hal ini akhirnya mengundang pertanyaan besar tentang sejauh mana kontribusi agama terhadap kekerasan yang terjadi. Fenomena ini juga memunculkan pertanyaan yang paling mendasar, apakah benar akar semua kekerasan yang terjadi ini ada pada "tradisi kekerasan Tuhan"? ${ }^{2}$ Banyak respons bermunculan dari berbagai kalangan terkait pertanyaan besar tersebut. Dalam konteks ini, Internet telah menjelma menjadi ruang tanpa batas untuk menyebarkan ideologi, merespons, menghujat dan bahkan mencari solusi fenomena kekerasan atasn nama agama.

Pada penelitian ini penulis menggunakan pendekatan cyber ethnography, yaitu menerapkan langkah-langkah etnografis dalam "lapangan maya." Secara

${ }^{1}$ Djamhari Makruf, "Radikalisme Islam di Indonesia: Fenomena Sesaat?." Dalam Bahtiar Effendy dan Soetrisno Hadi (Ed.), Agama \& Radikalisme di Indonesia (Jakarta: Nuqtah, 2007), 4.

${ }^{2}$ Sebagaimana yang disangkakan oleh Pallmeyer dalam Jack Nelson-Pallmeyer, Is Religion Killing Us? Violence in the Bible and the Quran (New York, The Continuum International Publishing Group: 2003).

${ }^{3}$ Penggunaan metode etnografi untuk sebuah penelitian di dunia maya — sebagaimana dikatakan oleh Wittel—adalah sesuai dengan konsep "lapangan" dalam studi etnografi yang lentur dan dapat diaplikasikan di "lapangan dunia maya" (cyberspace), lihat: A. Wittel, "Ethnography On the Move: From Field to Net to Internet," Forum: Qualitative Social Research 1(1) (2000, January), http://qualitative-research.net/index.php/fqs/article/viewArticle/1131/2517 (diakses tanggal 12 Februari, 2010) bandingkan dengan Annette Markham, "Reconsidering self and other: the methods, politics, and ethics of representation in online ethnography," dalam Handbook of qualitative research, ed. N.K. Denzin dan Y.S. Lincoln (Thousand Oaks: Sage, 2004), Christine Hine, Virtual ethnography (London, Thousand Oaks \& New Delhi: Sage, 2000), Kate Eichhorn, "Sites Unseen: Ethnographic Research in a Textual Community," Qualitative Studies in Education 14, 4 (2001): 565-78, Adi Kuntsman, "Cyberethnogrpahy as Home Work," Anthropology Matters Journal 6, 2 (2004), http://www.anthropologymatters.com (diakses tanggal 12 Februari, 2010). Karena memang cyber ethnography sendiri mengasumsikan bahwa apa yang berlaku di dunia maya tidaklah berbeda dengan apa yang berlaku di dunia nyata, lihat: Allison Cavanagh, "Behavior in Public?: Ethics in Online Ethnography," 
spesifik, penulis mengadopsi langkah-langkah kajian netnografi Kozinet sebagaimana dijelaskan oleh bagan berikut:

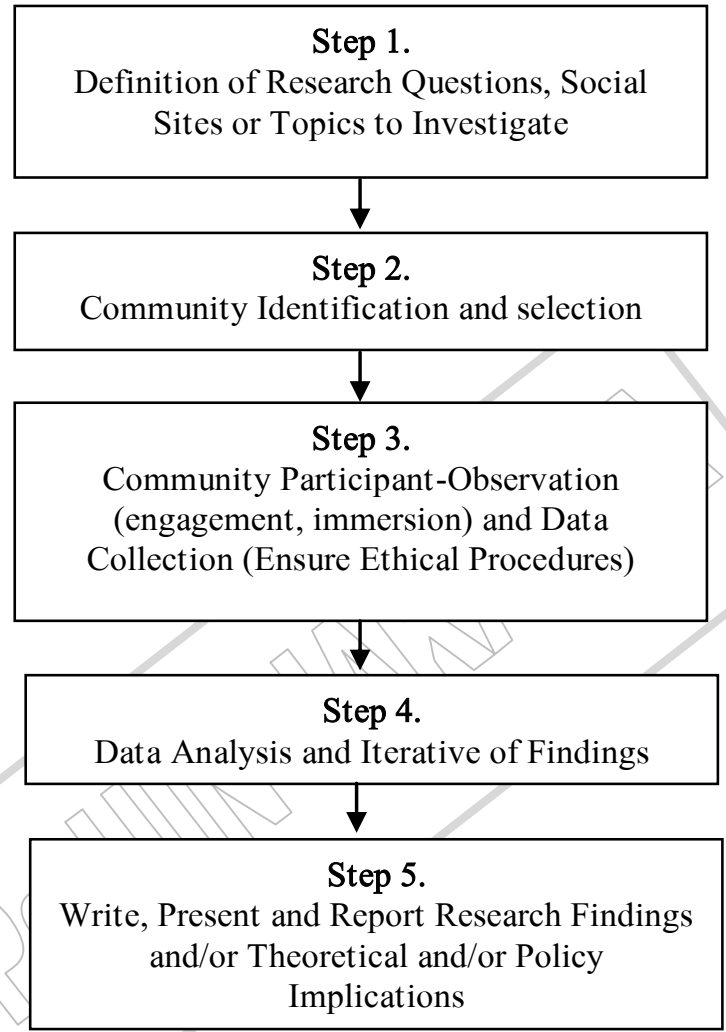

Gambar 1.

Alur kajian Netnografi Kozinets ${ }^{4}$

Pada langkah pertama, sebagaimana yang penulis paparkan pada pendahuluan artikel ini, penulis mengangkat isu upaya respons netizen Indonesia terhadap fenomena kekerasan atas nama agama yang terjadi di Indonesia. Langkah kedua, penulis menetapkan komunitas netizen Indonesia yang bergabung dalam situs Kaskus. Pemilihan situs Kaskus sebagai fokus kajian ini didasarkan pada Alexa Traffic Rank yang menetapkan Kaskus di tempat ke-7 situs yang paling banyak dikunjungi di Indonesia setelah Facebook

http://www.cybersociology.com/files/6_2 ethicsinonlineethnog.html (diakses tanggal 12 Februari 2010).

${ }^{4}$ Robert V. Kozinets, Netnography: Doing Ethnographic Research Online (London: Sage Publications Inc., 2010). 
dan Google tentunya. Untuk keterangan lebih lanjut, penulis akan memaparkan dalam sub bahasan khusus mengenai laman Kaskus.

Setelah menetapkan fokus kajian, penulis kemudian melakukan pengumpulan data dengan cara mendokumentasikan komentar-komentar Kaskuser (sebutan bagi para anggota Kaskus) terkait posting-posting yang mengangkat tema kekerasan atas nama agama. Dengan mengetikkan terma "kekerasan agama" di fitur search engine yang tersedia di pojok kanan atas laman situs Kaskus.us, keluarlah 30 posting yang mengandung terma yang dicari. Setelah membaca dan memilah lebih lanjut, penulis mendapatkan hanya 25 posting yang memang benar-benar berkaitan dengan tema kekerasan at as nama agama. Kemudian penulis mengklasifikasikan 26 posting tersebut ke dalam enam tema: agama dan kebencian, akar kekerasan atas nama agama, kekerasan antar umat beragama, kekerasan berdalih agama, solusi menghindari, dan Islam agama teroris/kekerasan.

Selain itu, penulis juga membuat web survey dan menyebarkan link web survey tersebut ke 4 forum yang ada di Kaskus; The Lounge, Berita dan Politik, Lifestyle, dan Spiritual dari tanggal 26 September hingga 23 Oktober 2011. Penulis juga menyebarkan link tersebut ke 150 akun Facebook yang termasuk dalam friend list akun Facebook penulis. Dalam web survey yang penulis buat, penulis menanyakan 7 pertanyaan untuk mengetahui identitas responden: seperti nama, id Kaskus (khusus bagi Kaskuser), id Facebook, jenis kelamin, agama, pekerjaan dan umur) dan 5 pertanyaan terkait fenomena kekerasan atas nama agama yang terjadi di Indonesia; penyebab utama terjadinya kekerasan atas nama agama, alasannya, seberapa besar pengaruh media (baik cetak maupun elektronik) terhadap kekerasan atas nama agama yang terjadi, alasannya, solusi apa yang dapat diambil agar tidak terjadi lagi kekerasan atas nama agama).

Dari web survey ini penulis mendapatkan 89 orang responden (29 Kaskuser dan 60 Fesbuker) dengan perbandingan 69 responden laki-laki dan 20 responden perempuan yang berumur paling banyak bersikar 21-25 tahun (31 repsonnden) dan 26-30 tahun (32 responden). Dilihat dari background keagamaan, mayoritas responden (68 responden) beragama Islam, 4 responden beragama Buddha, 7 responden beragama Kristen, 4 responden beragama Hindu dan 1 responden mengaku atheist. 89 responden yang didapat dari web survey ini memiliki pekerjaan yang bervariasi, mulai dari wartawan (1 responden), mahasiswa/i (25 responden), konsultan IT (4 responden), seniman (1 responden), hingga abdi pondok (1 responden).

Setelah mengumpulkan data-data dari para netizen, langkah selanjutnya adalah menganalisa data-data yang terkumpul. Dalam hal ini penulis menggunakan metode deskriptif konten analisis sebagaimana yang pernah 
dilakukan oleh Rasha ketika meneliti tanggapan dunia Arab pasca peristiwa 911 melalui tiga forum diskusi Arab online. ${ }^{5}$ Untuk kepentingan penelitian ini, komentar-komentar yang sifatnya "junk" (sampah) seperti: "pertamax, keduax" (kata lain dari pertama, kedua) dan seterusnya, "zzzzz" (eksperesi tidur) atau "hoaammm" (ekspersi ngantuk), komentar yang tidak secara eksplisit menyatakan persetujuan seperti "ijin nyimak aja" dan lain-lain, tidak diperhitungkan.

Secara singkat, pada artikel ini penulis akan "memperdengarkan" suarasuara masyarakat Indonesia yang tersimpan di ruang maya. Hal ini menjadi perlu untuk diangkat ke permukaan, mengingat suara mereka ternyata lebih nyaring, polos dan lebih solutif.

\section{Kaskus.us: Wadah Bebas Ber-kasak-kusuk}

Kaskus, yang merupakan singkatan dari "kasak-kusuk" merupakan forum komunitas online Indonesia terbesar dan menduduki peringkat kedua situs yang paling banyak dikunjungi di Indonesia. ${ }^{6}$ Sesuai dengan namanya "kasak-kusuk," forum ini merupakan tempat sekitar 2,5 juta Kaskuser (sebutan bagi member Kaskus) untuk berkasak-kusuk melakukan banyak hal; diskusi, ngobrol, debat, jual beli dan lain-lain.

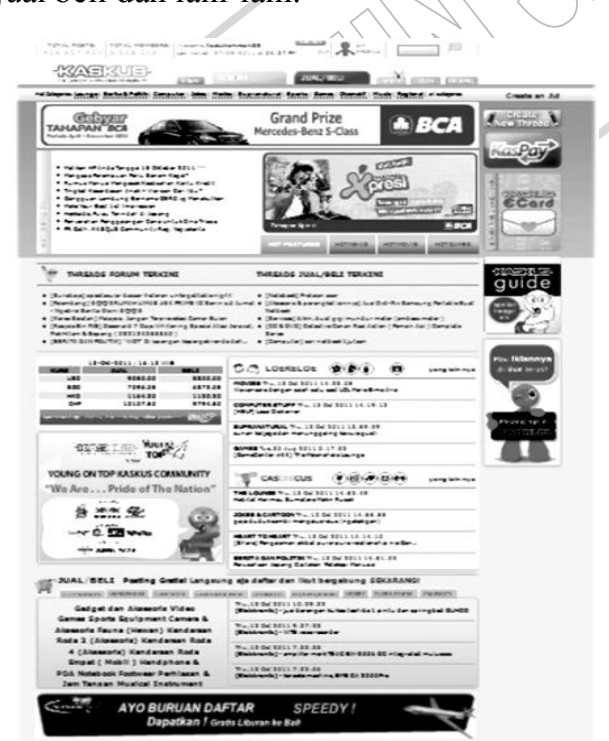

Kaskus digagas pertama kali pada tanggal 6 November 1999 oleh tiga mahasiswa Indonesia yang sedang belajar di Amerika Serikat, yaitu Andrew Darwis, Ronald Stephanus, dan Budi Dharmawan sebagai ajang pelepas rindu dengan kampung halaman. Setelah pengunduran diri Ronald dan Budi, Kaskus sempat mengalami stagnansi hingga datang Ken (sepupu Andrew) yang meminta Andrew untuk meneruskan mengembangkan Kaskus, mengingat Kaskus

\section{Gambar 2.} ternyata telah banyak diminati oleh masyarakat Tampilan Kaskus

\footnotetext{
${ }^{5}$ Rasha A. Abdullah, "Islam, Jihad, and Terrorism in Post-9/11 Arabic Discussion Boards" Journal of Computer Mediated Communication 12 (2007): 1063-1081

${ }^{6}$ Berdasarkan data dari alexa.com pada tanggal 13 Oktober 2011, lebih jelasnya silakan kunjungi http://www.alexa.com/topsites/countries/ID
} 
Indonesia. Dari sejak itulah, Kaskus mulai banyak melalukan perubahan, khususnya, dari sisi konsep sehingga pada hari jadinya yang ke 11 (6 November 2010), Kaskus tetap dapat menunjukkan eksistensi dan kredibilitasnya sebagai situs terpopuler se-Indonesia. ${ }^{7}$

Pengguna Kaskus kebanyakan berasal dari kalangan remaja laki-laki yang tidak hanya berasal dari Indonesia tetapi juga dari luar Indonesia, seperti Amerika, Singapore, Australia dan lain-lain.

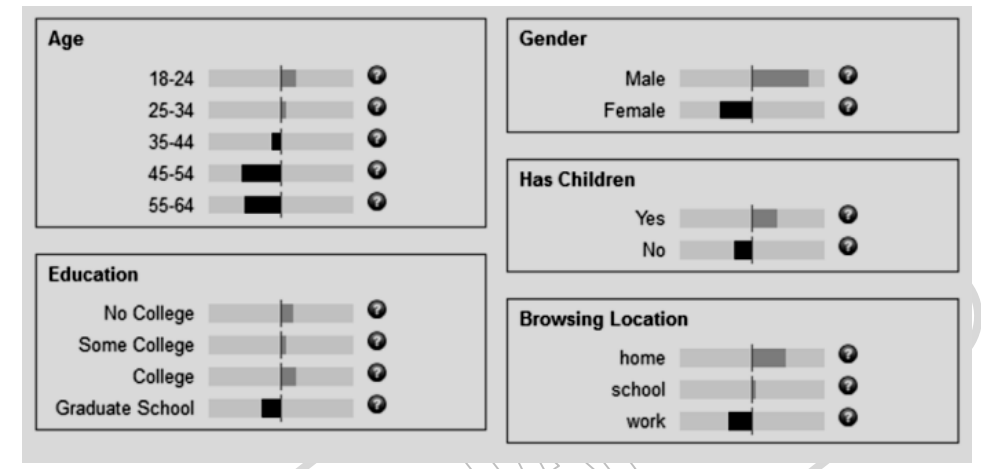

Gambar 3.

Demografi Kaskuser ${ }^{8}$

Secara garis besar, Kaskus memiliki dua ruang utama; FORUM dan FJB (Forum Jual Beli). FORUM sendiri merupakan fitur yang diberikan oleh Kaskus untuk berbagi segala hal yang diklasifikasikan dalam empat ruang; LOEKELOE, CASCISCUS, KASKUS CORNER dan REGIONAL. Ruang "LOEKELOE" merupakan ruang bagi para Kaskuser untuk berbagi segala macam informasi, minat, hobi, ide, pengalaman dan tips dengan komunitaskomunitas yang menarik. Ruang ini memiliki banyak 26 "pintu" yang sangat beragam, seperti AMH (tempat share segala hal tentang Anime, Fanstuff, Manga, dll), COMPUTER STUFF (tempat berbagi seputar dunia komputer seperti Linux, Hardware, Website, Applications \& Games, dll). Terdapat juga pintu khusus bagi pecinta MUSIC, OTOMOTIF, TANAMAN, PETS, GADGET hingga pintu SUPRANATURAL yang merupakan wadah berbagi seputar dunia spiritual dan budaya.

Sedangkan FJB (Forum Jual Beli) adalah ruang khusus bagi Kaskuser untuk berniaga berbagai macam barang atau menjual jasa. FJB menyediakan

\footnotetext{
${ }^{7}$ Muhammad Chandrataruna, "11 Tahun Popularitas Kaskus Tak Terbendung," diakses online dari http://teknologi.vivanews.com/news/read/187470-11-tahun--popularitas-kaskus-takterbendung pada tanggal 13 Oktober 2011

${ }^{8}$ www.alexa.com/siteinfo/kaskus.us
} 
30 pilihan kategori barang dan jasa seperti handphone, barang antik, property dan jasa service.

Ruang lain yang terdapat di dalam Kaskus adalah CASCISCUS, wadah bagi Kaskuser untuk bergosip, curhat, diskusi segala info seputar gaya hidup, trend hingga berita-berita terkini. Ruang ini memiliki 18 "pintu", di antaranya, WELCOME TO KASKUS (sebuah pintu khusus yang dibuat untuk mengirimkan kritik, saran dan pertanyaan seputar Kaskus, Donatur, arsip forum dan lain-lain), SURAT PEMBACA, BERITA DAN POLITIK, DEBATE CLUB (tempat Kaskuser berdiskusi atau lebih tepat beradu argumen mengenai berbagai isu).

Selain LOEKELOE dan CASCISCUS, Kaskus juga memiliki KASKUS CORNER yang berisi update info kegiatan-kegaitan seperti Baksos, Gathering, Seminar dll yang diselenggarakan oleh Kaskus dan melibatkan Kaskuser. KASKUS CORNER memiliki empat pintu, KASKUS PEDULI, KASKUS PROMO, CINTA INDONESIAKU dan KASKUS CELEB (yang berisi info selebritis yang turut ngaskus). Sebagai ajang silaturahmi Kaskuser yang berada di luar Indonesia, Kaskus membuka ruang khusus yang diberi nama REGIONAL. Ruang ini memiliki enam pintu silaturahim dari berbagai belahan dunia; ASIA (China, Japan, Korea Selatan, Malaysia, Singapore dll), AUSTRALIA (Brisbane, Melbourne, Perth, Sydney dan lain-lain), INDONESIA, USA dan OTHER REGIONAL (seperti Canada, Timur Tengah dan lain-lain).

Untuk melengkapi kebutuhan para penggunanya, Kaskus juga menyediakan beberapa fitur seperti; KasPay (sebuah sistem pembayaran secara online yang dapat digunakan tidak hanya di Kaskus tetapi dapat digunakan di situs-situs lain yang berafiliasi dengan Kaspay), e-pulsa (layanan yang menyediakan fasilitas pengisian pulsa dari semua operator dengan sistem pembayaran menggunakan KasPay), Kaskus Ads (layananan untuk menempatkan iklan di Kaskus dengan biaya yang cukup murah).

Layaknya sebuah masyarakat nyata, komunitas maya juga memiliki tatanan kehidupan tersendiri. ${ }^{9}$ Dalam Kaskus, Kaskuser memiliki sistem tatanan kehidupannya tersendiri. Terkait dengan sisi kelompok sosial, misalnya, Kaskus memiliki sistem kepangkatan. Pangkat/tag/rank/titel setiap forum akan berbeda, tetapi pada dasarnya terbagi menjadi dua; berdasarkan jumlah posting (0-99 newbie, 100-499 Kaskuser, 500-749 aktivis Kaskus, 750999 Kaskus holic, 1.000 - 3.999 Kaskus addict, 4.000 - 9999 Kaskus maniac,

${ }^{9}$ Sayling Wen, Future of the Media (Batam: Lucky Publishers, 2002). Bandingkan dengan apa yang ditulis oleh M. Burhan Bungin tentang masyarakat maya dalam Sosiologi Komunikasi; Teori, Paradigma, dan Diskursus Teknologi Komunikasi di Masyarakat (Jakarta: Prenada Media Group, 2006), 160-172. 
$10.000-24.999=$ Kaskus geek, $25.000-49.999=$ Kaskus freak, $50.000-=$ made in Kaskus) dan pengelola seperti: moderator (kepercayaan administrator forum untuk menjaga forum dan ini diangkat bukan berdasarkan jumlah postingan atau kapan dia joint, melainkan admin menilai kalo ybs layak untuk dijadikan moderator berdasarkan banyak pertimbangan), regional leader (user yang dipercaya untuk mengatur diforum regional user yang bersangkutan), mysterious man (team server Kaskus), pool master of the year (pemenang game pool yang diadakan Kaskus beberapa tahun yang silam), dan Admin/coadmin/sleepy admin (administrator Kaskus).

Tidak hanya menyangkut reputasi dan titel, forum komunitas yang sudah eksis lebih dari 11 tahun ini juga memiliki bahasa, istilah, dan singkatan tersendiri yang digunakan sebagai identitas; diantaranya yang paling banyak digunakan adalah "Agan," istilah lain juragan (bahasa Sunda), panggilan kepada sesama member Kaskus, "Afgan" = sadis (biasanya digunakan ketika tawar menawar di Forum Jual Beli), "Cendol" = reputasi bagus, ditandai dengan kotak kecil berwarna hijau di bawah ID user, "Mimin" = istilah lain Administrator Kaskus, "Momod" = istilah lain Moderator, dan masih banyak lagi.

Ketika berkomunikasi dengan sesamanya, Kaskuser juga menggunakan beberapa animatif emoticon untuk mewakili kondisi psikologisnya ${ }^{10}$ sehingga membuat posting menjadi lebih interaktif dan hidup. Contoh animatif emoticon yang ada diant aranya adalah:

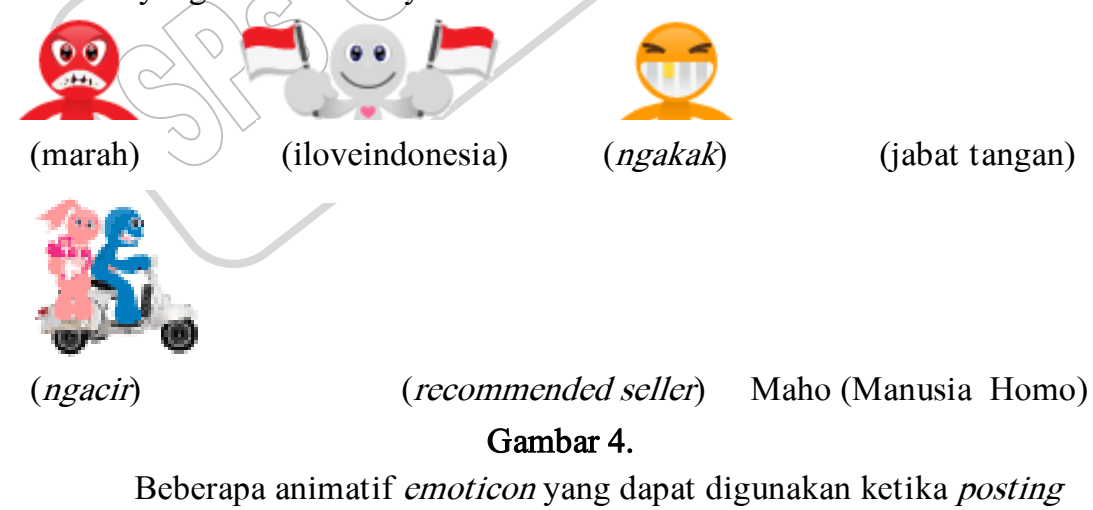

Dalam konteks penelitian ini, penulis menemukan satu hal lain yang tidak kalah penting dari portal Kasak-kusuk ini, yaitu pernyataan bahwa, "Kaskus is providing basic human rights such as freedom of speech.” Pernyataan yang

\footnotetext{
${ }^{10}$ Sebagaimana yang dinyatakan oleh Wallace bahwa dunia maya ternyata tidak kosong dengan nuansa-nuansa psikologis, selengkapnya baca: Patricia Wallace, The Pscychology of The Internet (Cambridge: Cambridge University Press, 1999).
} 
dapat ditemukan di bagian paling bawah dari situs ini, menurut penulis, memiliki urgensi tersendiri khususnya bagi portal yang menyediakan wadah untuk berbagi banyak hal. Dengan pernyataan ini, para pengguna Kaskus dapat merasa tenang mengutarakan pendapat mereka walaupun tentunya pihak pengelola Kaskus juga menetapkan beberapa peraturan bagi para penggunanya. Dan pernyataan selanjutnya yang menyatakan bahwa, "By using Kaskus, you agree to the following conditions: Use this site at your own risk and it is not the risk of the owner or the webhost. If you do not agree to these terms, please do not use this service or you will face consequences. USING THIS SITE INDICATES THAT YOU HAVE READ AND ACCEPT OUR TERMS. IF YOU DO NOT ACCEPT THESE TERMS, YOU ARE NOT AUTHORIZED TO USE THIS SITE” tentunya bukan sikap cuci tangan pihak pengelola Kaskus atas konten-konten yang ada, tetapi sebagai sikap yang diambil untuk mendorong sikap kedewesaan para Kaskuser agar bertanggung jawab atas apa yang mereka lakukan selama di dalam Kaskus.

\section{Fakta Kelam Keberagamaan di Indonesia}

Berbicara masalah kekerasan atas nama agama tentunya tidak dapat dilepaskan dari fenomena munculnya gerakan Islam garis keras. Di Indonesia sendiri, hal ini tentunya bukanlah barang baru. Ketika kita membuka sejarah, kita menemukan gerakan DI/TII, Darul Islam/Tentara Islam Indonesia. Gerakan DI/TII muncul ketika gerilyawan di bawah pimpinan Kartosuwiryo menolak perjanjian Renville dengan pemerintah Belanda sebagai bentuk perlawanan terhadap Pemerintah Indonesia yng menetujui perjanjian tersebut. Kartosuwiryo dan kelompoknya menjadikan syariah sebagai dasar hukum bagi kelompoknya dan menamakan dirinya sebagai negara Islam Indonesia (NII. Gerakan Darul Islam ini berhenti ketika semua pimpinan tertangkap atau terbunuh pada awal 1960-an.

Gerakan Islam garis keras muncul kembali pada awal tahun 1970-an dan 1990-an. Kelompok seperti Komando Jihad, Ali Imron, Terror Warman dan semacamnya muncul ke permukaan. Kelompok ini menyatakan perang terhadap komunisme di Indonesia. Ketika masa reformasi, gerakan Islam garis keras juga bermunculan. Gerakan Front Pembela Islam, Laskar Jihad, Majelis Mujahidin Indonesia, dan lain-lainnya menunjukkan hal itu. Kemunculan mereka sebagai wujud dari respon psikologis yang tertunda (delayed psychological responses) terhadap kekuasan yang otoriter, sesungguhnya adalah fenomena biasa ketika pintu keterbukaan terbuka. ${ }^{11}$

\footnotetext{
${ }^{11}$ Djamhari Makruf, "Radikalisme Islam di Indonesia: Fenomena Sesaat?.”, 8-9. Kelanjutan geneologi gerakan Islam radikal pasca pemerintahan Soeharto dapat dibaca lebih lanjut di Martin
} 
Setelah munculnya gerakan Islam garis keras, konflik antara mayoritas dan minoritas menambah panjang catatan merah keberagamaan di Indonesia serta mengindikasikan semakin buruknya hubungan tersebut baik etnis, ras, kelompok ataupun agama, ${ }^{12}$ seperti, konflik antara etnik minoritas Madura dan Dayak di Kalimantan Barat dan Tengah di tahun 1999 dan terjadi kembali di tahun 2001, ${ }^{13}$ pertikaian antara minoritas Muslim dan Kristen di Maluku dan Poso di sepanjang tahun 1998-2000, ditambah lagi dengan peristiwa penyerangan terhadap jemaat Ahmadiyah di Cikeusik, Banten pada 6 Februari 2011 dan pembakaran gereja serta sekolah di Temanggung, Jawa Tengah pada 8 Februari 2011.

Berdasarkan survey Moderate Moslem Society (MMS) hingga tahun 2010 tindakan minoritas versus mayoritas masih terjadi dan cenderung meningkat. MMS mencatat sekitar 81 kasus intoleransi beragama di Indonesia sepanjang 2010. Angka ini naik 30\% dari tahun sebelumnya yang hanya mencapai 59 kasus. Daerah tempat kasus-kasus tersebut terjadi, ada tiga daerah yang paling tinggi angka tingkat intoleransi yakni Jawa Barat (73 kasus), Sumatera Barat (56 kasus) dan Jakarta (45 kasus). ${ }^{14}$ Laporan lain dari Jaringan Masyarakat Anti Kekerasan (Jamak) Jatim mengungkapkan data kekerasan berbasis agama (pelanggaran kebebasan beragama) di Jatim melonjak. Hingga Oktober 2010, terdapat 14 peristiwa kekerasan dan angka ini lebih tinggi dibandingkan tahun lalu yang berjumlah 12 peristiwa. Kekerasan yang dimaksud tersebut meliputi penyerangan, perusakan, intimidasi, pemukulan, penganiayaan, pemaksaan pindah keyakinan beragama dan pengusiran. ${ }^{15}$ Kesimpulan yang sama pun dilaporkan oleh The Wahid Institute (WI). WI membagi bentuk pelanggaran hak-hak beragama atau berkeyakinan menjadi dua kategori yakni pembatasan atau pelanggaran oleh negara atau mengatasnamakan negara. Pelanggaran

van Bruinessen, "Genealogies of Islamic Radicalism in post-Suharto Indonesia," South East Asia Research vol. 10, no.2 (2002), 117-154.

${ }^{12}$ Asia Briefing N ${ }^{\circ} 114$, "Indonesia: "Christianisation" and Intolerance," (International Crisis Group (ICG): 2010), diakses dari http://www.crisisgroup.org/en/regions/asia/south-eastasia/indonesia/B114-indonesia-christianisation-and-intolerance.aspx, 12 Februari 2011. Lihat juga Laporan Kebebasan Beragama/Berkeyakinan dan Toleransi 2010 dan Laporan Tahunan the Wahid Institute, 2010. Dapat diunduh online dari http://wahidinstitute.org/files/_docs/FULL\%20REPORT-

ANNUAL\%20REPORT\%20WI\%202010.pdf

13“Pemerintah Belum Serius Tangani Konflik Dayak-Madura," (Tempointeraktif: 2001), diakses dari http://www.tempointeraktif.com/hg/nasional/2001/06/24/brk,20010624-06,id.html, 12 Februari 2011

${ }^{14}$ Donny Andhika AM, "Kekerasan terhadap Kerukunan Beragama Naik 30 Persen," diakses dari $\quad$ http://www.mediaindonesia.com/read/2010/12/22/189965/92/14/Kekerasan-terhadapKerukunan-Beragama-Naik-30-persen, 11 Februari 2011.

${ }^{15}$ Rahardi Soekarno J, “Angka Kekerasan Beragama di Jatim Melonjak,” (Berita Jatim: 2010), diakses dari http://www.beritajatim.com/detailnews.php/6/Politik \& Pemerintahan/201010-26/81954/Angka_Kekerasan_Beragama_di_Jatim_Melonjak, 11 Februari 2011 
tersebut tercatat dimulai dari penyesatan terhadap kelompok/individu hingga perusakan rumah ibadah agama lain. ${ }^{16}$

Situasi tersebut di atas mengundang kritik dan perdebatan dari berbagai kalangan. Terkait dengan masalah Ahmadiyah, misalnya, Azyumardi Azra mengatakan bahwa pelarangan aktivitas Jemaat Ahmadiyah bertentangan dengan UUD 1945. Pertama tentang kebabasan beragama dan kedua kebebasan berserikat dan berkumpul. ${ }^{17}$ Opini serupa juga disampaikan Hasyim Muzadi (tokoh NU). Ia menilai membubarkan keyakinan itu tentu tidak bisa. Akan tetapi, mencegah dampak dari Islam yang di luar mainstream akan mungkin dilakukan. Hasyim beranggapan sebaiknya para kyai dapat mengembalikan pengikut Ahmadiyah kembali ke Islam yang mainstream dan dapat diberi pencerahan. ${ }^{18}$ Lebih jauh lagi, Sholahudin Wahid mengungkapkan bahwa Indonesia harus saling bekerja sama, saling mendukung, tidak mendahulukan diri masing-masing serta saling menyemangati dalam menghadapi kesulitan. Dalam menghadapi masalah keberagamaan, perbedaan agama atau ras tidak boleh menjadi alasan untuk tidak bekerja sama." 19

Selain konflik minoritas dan mayoritas, Indonesia tentunya tidak dapat lupa dengan catatan angka ledakan bom pernah terjadi di negeri mayoritas muslim ini. Kompas.com memberikan catatan panjang rentetan ledakan bom yang pernah terjadi di Indonesia sejak tahun $2000:{ }^{20}$ dua belas bom meledak atau diledakkan oleh para pelaku bom bunuh diri di tempat-tempat ramai (di antaranya: kantor kedutaan besar, hotel, rumah makan, pusat perbelanjaan, dan masjid), setidaknya 46 nyawa melayang dan ratusan orang menderita lukaluka serius.

Hal lain yang turut menambah panjang catatan kelam keberagamaan di Indonesia hingga menjadi sorotan dunia adalah fenomena terorisme. Sejarah mencatat peristiwa panjang fenomena terorisme, mulai dari pembajakan pesawat Garuda DC-9 Woyla jurusan Palembang-Medan pada tanggal 28 Maret

\footnotetext{
${ }^{16}$ Laporan Kebebasan Beragama/Berkeyakinan dan Toleransi 2010, (The Wahid Institute: 2010)

${ }^{17}$ Adi Lazuardi, “SKB 3 Menteri Sebaiknya Dijadikan UU,” (detiknews: 2011), diakses dari http://www.detiknews.com/read/2011/02/12/141818/1570047/10/azyumardi-azra-skb-3-menterisebaiknya-dijadikan-uu?nd991103605, 12 Februari 2011

${ }^{18}$ Adi Lazuardi, "Hasyim Muzadi Nilai Ahmadiyah Tidak Bisa Dibubarkan," (detiknews: 2011), diakses dari http://www.detiknews.com/read/2011/02/12/110434/1569963/10/hasyimmuzadi-nilai-ahmadiyah-tidak-bisa-dibubarkan, 12 Februari 2011.

19،Kerukunan Agama Memburuk: Rapor Merah Menteri Agama KIB II," (Suara Pembaruan: 2011), diakses dari http://www.suarapembaruan.com/index.php?detail=News\&id=27044, 14 Februari 2011.

${ }^{20}$ Sumber http://www.kompas.com/lipsus072009/ledakanmegakuningan
} 
1981 menjadi "jihad" pertama bagi para pelaku terorisme di Indonesia, ${ }^{21}$ Bom bali 1 pada tahun 2002 dan menyusul bom bali 2 tiga tahun setelahnya, ${ }^{22}$ hingga ledakan bom bunuh diri Si Jangkung Penjaja Parfum di masjid Mapolresta Cirebon pada saat salat Jumat, April 2011 yang lalu. ${ }^{23}$

\section{Islam Agama Teroris/Kekerasan: Perspektif Kaskuser}

Klaim Islam sebagai agama teroris merupakan tema yang hangat dibahas di kalangan Kaskuser. Penulis menemukan tiga posting yang mengangkat masalah klaim tersebut. Pertama, posting yang mengangkat pernyataan putra Perdana Menteri Israel yang menyebut Islam agama teroris. Posting yang ditulis oleh $i d$ "pahamkekerasan" ini ditutup dengan kata-kata provokatif "enak aja $l u$ nyebut agama Islam agama teroris. Ini juga agama para pemerkosa, koruptor, pedophil dan penjarah. Agama untuk semua umat manusia." Posting ini kemudian mendapatkan 11 respons. Satu orang newbie dengan id "royal.pains2" meng-iya-kan bahkan turut menjelekkan Islam dengan menulis "sudah gak heran,... and sudah jadi rahasia umum seluruh dunia kalee,...emang terilhami dan terinspirasi dari sang guru besar junjungan : MAHOOMAD aka MADMAHOO.." Tiga orang menyatakan tidak setuju dengan klaim Islam agama teroris, justru Israel lah yang teroris sesungguhnya, sebagaimana ditulis oleh seorang Kaskuser dengan id "d.banditz" "bukannya yang ngejajah itu yang layak disebut teroris yah. Teroris kok ngomong teroris..udah gila ini orang Zionis." Dua komentar lainnya lebih mendukung agar posting tersebut dihapus karena sudah mengandung SARA, sedangkan lima komentar lainnya lebih bersifat junk.

Kedua, posting yang ditulis oleh seorang Kaskuser dengan id "Yvain" menukil tulisan dari http://media-Islam.or.id/2010/04/25/apakah-Islam-agamaterorispaling-keras-di-dunia/ tentang benarkah Islam agama penyebar kekerasan di dunia ini? Dalam posting tersebut, ia mengomentari dengan menyayangkan posisi Islam yang terpojok dan sering kali menjadi kambing hitam. "Padahal Islam adalah korban kebrutalan dari masa ke masa dengan orang-orang munafik yang sok suci. Apakah hanya karena alasan orang-orang yang termakan nafsu dan mengartikan al-Quran seenak jidat??” begitu tulisnya.

\footnotetext{
${ }^{21}$ Muhammad Saifullah, "Woyla, Terorisme Pertama di Indonesia," diakses online dari http://news.okezone.com/read/extend/2009/10/15/343/265886/woyla-terorisme-pertama-diindonesia pada tanggal 9 Oktober 2011

${ }^{22}$ Peristiwa bom bali ini juga tercatat di Encyclopedia of Terrorism yang ditulis oleh Cindy C Bombs dan Martin Slann (New York: Fact on File, Inc. An imprint of Infobase Publishing, 2007).

${ }^{23}$ Asrori S. Karni, Wisnu Wage Pamungkas, Sandika Prihatnala, dan Gandhi Achmad, "Bom si Jangkung Penjaja Parfum," diakses online dari http://arsip.gatra.com/artikel.php?pil=23\&id=147407 pada tanggal 9 Oktober 2011.
} 
Posting ini kemudian mendapat 49 respons. Dua di antaranya mengatakan Islam memang agama penyebar kekerasan, sebagaimana yang ditulis oleh seorang newbie dengan id "bu.yahoo.007" yang menulis "dasar bangsat membela diri pake bawa-bawa keburukan agama laen. Dimana2 kristen dan agama laen gak pernah mau mengIslam dunia - gak kek agam elo yang sedikitsedikit ngebom, sedikit-sedikit perkosa, sedikit-sedikit minta dihormatin puasanya. Buruk muka cermin dibelah, kesiaaaaan deh loe!" 15 orang berkomentar Islam bukanlah agama penyebar kekerasan, diantaranya diakui oleh orang Kristiani dengan id "detective007" yang menulis "TS ${ }^{24}$ lagi bosan barangkali tuh.. Agama Islam sumber kekerasan? Yakin loe? Gue Kristiani, dan temen Gue Muslim. Adem ayem aja tuh, komplek Gue yang agamanya macemmacem (Islam, Kristen, Katolik, Budha), juga gak ada ribut-ribut. Malah sering ngerumpi lagi (maklum cewek). Makanya jangan kebanyakan nonton, ntar gampang terkena provokasi loh... Btw kelompok Gue agamanya beda-beda $1 o h$. Gak pernah ribut-ribut tuh.." 11 komentar lainnya mengajak untuk lebih bisa menerima perbedaan dan menjaga perdamaian di Indonesia, sedangkan 21 lainnya hanya bersifat junk yang tidak ada hubungannya dengan isi posting.

Ketiga, posting yang ditulis oleh seorang Kaskus addict dengan id "iisengi" yang berjudul "[MENGGUGAT] ISLAM, Agama Barbar yang Selalu Ngajarin KEKERASAN dan ANARKI" ini memposting ulang artikel yang ditulis oleh Emha Ainun Nadjib ${ }^{25}$ yang secara garis besar berisi hujatan kepada pihak-pihak yang telah memojokkan Islam. Posting ini juga disertai polling "Islam agama yang damai atau tidak menurut agan?" dengan pilihan A). Islam agama damai, yang rusuh adalah oknum yang salah paham dan ingin ngejelekin Islam. B). Islam memang agama kekerasan. Hasil polling tersebut (sampai tanggal 16/10/11) menunjukkan, dengan total voter sebanyak 1055, 861 atau 81.61\% menyatakan bahwa Islam agama damai, yang membuat kerusuhan sebenarnya hanyalah oknum yang salah faham dan ingin menjelek-jelekkan Islam. Dan 194 atau 18.39\% menyatakan ya, memang Islam agama kekerasan.

Dari komentar-komentar para Kaskuser terhadap posting dan thread yang mengangkat tema klaim Islam agama teroris/kekerasan, dapat disimpulkan bahwa walaupun ada dari beberapa Kaskuser yang memandang sinis terhadap Islam dengan mengatakan bahwa Islam adalah agama penyebar kekerasan di dunia ini, mayoritas Kaskuser justru berpandangan sebaliknya. Hal ini dapat dilihat dari hasil polling (sebagaiaman disebutkan di atas) yang menunjukkan bahwa $81.61 \%$ menyatakan bahwa Islam agama damai, segala bentuk kekerasan yang mengatasnamakannya merupakan tindakan oknum tidak

\footnotetext{
${ }^{24}$ TS kependendekan dari "Thread Starter" istilah yang berarti si penuls posting.

${ }^{25}$ Artikel selengkapnya dapat diakses di http://www.kaskus.us/showthread.php?t=7143285
} 
bertanggungjawab. $^{26}$ Pernyataan seorang Kaskuser nonmuslim yang menceritakan pengalaman hidupnya yang damai bersama kawan-kawan muslimnya semakin memperkuat bahwa Islam tidak membawa risalah kekerasan ke dunia ini.

Munculnya klaim Islam sebagai agama teroris/kekerasan, di sisi lain, dapat dilihat sebagai cambuk keras bagi umat Islam sendiri untuk mampu membuktikan ketidak beneran klaim tersebut dengan menerjemahkan risalah Islam ke berbagai ruang yang ada dalam masyarakat dengan baik.

\section{Agama, Kebencian, dan Kasus Kekerasan Berdalih Agama menurut Kaskuser}

Pada tanggal 17-03-2011, seorang newbie dengan id "PenelitiSARA" membuat thread dengan judul "(Tanya gan) MENGAPA AGAN SAMPAI BENCI SAMA AGAMA LAIN?? Kok pake kekerasan sih?". Thread tersebut selengkapnya adalah sebagai berikut:

Kenapa sih agan kok masih benci banget sih sama agama lain? Mengapa harus menghalalkan KEKERASAN bahkan PEMBUNUHAN kepada para pemeluknya??? Yang paling parah menghalalkan PEPERANGAN bahkan yang terparah lagi menjadi BOM BUNUH DIRI kepada mereka? Simplenya gan: Halakkah memakai: KEKERASAN, PEMBUNUHAN, PEPERANGAN, TERORISME, BOM BUKU, BOM BUNUH DIRI dalam melindungi agama agan dari pengaruh "sesat" orang lain???

Thread ini mendapatkan 10 komentar yang dapat digolongkan menjadi; pertama, komentar yang menyatakan menghargai agama lain dan tidak membenci. Empat Kaskuser menyatakan hal demikian, diantaranya seorang Kaskus maniac dengan id "hciq1404" yang memberi komentar "siapa yang benci? Ane kagak tuh gan. Hargai Umat Beragama.” Kedua, komentar yang menyatakan tidak tertarik bahkan bosan dengan jenis isu seperti ini dan menyarankan agar tidak terjadi keributan di forum. Dan satu orang Kaskuser yang memiliki id "abushodiq" menjawab serius "Simplenya gan: Halalkah memakai: 1. Kekerasan apa yang dimaksud kekerasan di sini? Potong tangan

\footnotetext{
${ }^{26} \mathrm{Hal}$ ini sesungguhnya masih menjadi pertanyaan besar di kalangan para orientalis, diantaranya Robert Spencer yang menulis "Islam Unveiled." Dalam bukunya tersebut, Spencer mempertanyakan pernyataan George W. Bush pada akhir 2001 bahwa para pelaku terror sesungguhnya telah melanggar ajaran fundamental Islam. Mereka melakukan hal yang sebenarnya dilarang oleh Islam itu sendiri. Lebih lanjut Spencer mengatakan jika kita tidak boleh memberikan justifikasi negative terhadap Kristen atas dosa orang Kristen tertentu, maka cukup adil jika kita juga tidak memberikan klaim negatif pada Islam atas kelakuan oknum dari orang Islam tertentu. Tapi kemudian Spencer meragukan hal tersebut dengan mengatakan bahwa realitas sesungguhnya tidak semudah itu karena menurutnya memang ada beberapa kesamaan antara Islam dan Kristen tapi banyak hal lain yang justru sangat berbeda antara keduanya. Lihat: Robert Spencer, Islam Unveiled (San Fransisco: Encounter Books, 2002).
} 
kekerasan maka halal bagi pencuri, cambuk halal bagi pezina dan lain-lain, 2. Pembunuhan. Mengaku nabi= penggal. memberontak pemerintahan sah ( yang pemimpinnya masih sholat) = penggal, dan lain-lain, sebaiknya tidak disebutkan 3. Peperangan. Perang wajib bagi siapa yang melawan agama Allah. 4. Terorisme. Islam rohmatan lilalamin, teroris = sesat. 5. Bom Buku (ana baru dengar, gak paham maksud dari bom buku ) 6. Bom bunuh diri. Setahu ana : dengan alasan apapun $=$ haram. Yang menghalalkan $=$ teroris."

Perbincangan mengenai kebencian terhadap pihak yang memiliki ideologi berbeda berlanjut ke perbincangan yang lebih menjurus menyoroti kasus-kasus kekerasan atas nama agama yang terjadi di Indonesia. Dalam konteks ini, penulis mendapatkan lima posting yang termasuk dalam kategori pembahasan kekerasan antar umat beragama: posting mengenai berita dua pendeta di Gereja Huria Kristen Batak Potestan (HKBP) Ciketing, Bekasi, yang dipukuli dan ditusuk; ${ }^{27}$ posting mengenai pernyataan Menteri Agama tentang tingginya angka kekerasan bernuansa agama; ${ }^{28}$ posting mengenai aksi damai 1000 lilin tolak kekerasan terhadap kebebasan beragama; ${ }^{29}$ posting mengenai pernyataan Ketua Umum Partai Damai Sejahtera (PDS) yang ingin menebas kekerasan terhaap etnis dan agama; ${ }^{30}$ dan posting pernyataan anti kekerasan antar umat beragama. $^{31}$

Di antara lima posting yang ada, posting terakhir (pernyataan anti kekerasan antar umat beragama) adalah posting yang paling banyak mengundang respons para Kaskuser. 53 orang menyatakan setuju dan mendukung aksi anti kekerasan antar umat beragama, karena menurut mereka pada dasarnya tidak ada agama yang mengajak pada kekerasan. Tiga orang mengomentari akar permasalahan kekerasan antar umat beragama terjadi di indonesia karena di Indonesia masih banyak orang pintar namun dangkal. Satu orang dengan id lismax memberikan motivasi "not everyone who drops shit on you is your enemy. Not everyone who gets you out of shit is your friend. And when you are in deep shit, keep your mouth shut!"

Fenomena kekerasan atas nama agama yang terjadi di Indonesia baik berbentuk bom bunuh diri, kekerasan terhadap minoritas dan lain-lain ternyata

\footnotetext{
27، Tindak kekerasan terhadap kebebasan beragama di Indonesia kembali terjadi," diposting oleh meonk.moron pada 12/09/2010 10:12 PM, http://archive.kaskus.us/thread/5267193

28“Menag: Kekerasan Bernuansa Agama Cukup Tinggi," iposting oleh Jibril Avessina pada 21/02/2009 06:24 PM

29،Aksi damai 1000 lilin tolak kekerasan terhadap kebebasan beragama," diposting oleh roony12 pada 16/09/2010 07:54 PM, http://archive.kaskus.us/thread/5304634

30، (P) R. Hutasoit: PDS akan Menebas Kekerasan thd Etnis \& Agama ttt oleh kelompok ttt!," diposting oleh marvell 707 pada 09:34PM, http://archive.kaskus.us/thread/1070447

31، Thumbs up Anti kekerasan antar umat beragama," diposting oleh therusty pada 08-022011, 07:58 PM
} 
cukup menjadi concern para Kaskuser. Dalam hal ini, penulis mendapatkan dua posting yang mengangkat fenomena kekerasan berdalih agama yang keduanya menyita perhatian banyak Kaskuser, diantaranya adalah posting dengan judul "Exclamation Katakan tidak untuk segala kekerasan berdalih agama!"32 Posting yang ditulis oleh seorang Kaskus addict dengan id ollandkece ini (dan posting lain yang hampir mirip diposting oleh seorang Kaskuser dengan id nafsulelaki dengan judul "Kapan kalian Dapat Mandat?? "NO” Untuk KekerAsan Berdalih Agama) menampilkan foto hukum rajam di Somalia, foto anggota ahmadiyah yang disiksa massa hingga tewas, foto bom bali tahun 2002 yang menewaskan 202 orang tak berdosa dan melukai 209 orang, dan ditutup dengan pertanyaan "bagaimana kau begitu berani mengatas-namakan tuhan ketika dengan pongah kau melibas mereka yang sedang mencari jalan menuju kepada-Nya?"33

Posting ini mendapatkan 32 respons dari para Kaskuser. 20 orang menyatakan setuju untuk menghentikan segala tindak kekerasan atas nama agama dan mengajak untuk menjaga perdamaian, diantaranya adalah pernyataan seorang Kaskus addict dengan id "sollami" yang menyatakan "Sekejam-kejamnya orang pasti ada belas kasihnya juga. Tapi juga gan jangan sampai kita terpecah karena beda agama dan keyakinan kita untuk peperangan antara agama gan. Kita saudara gan dari dulu. Semoga Indonesia tidak ada peperangan antara umat agama lagi." Atau pernyataan boyszsocool "stuju gan. Buddhism love peace.." Walaupun ada seorang Kaskus addict yang mengomentari pernyataan bahwa Islam itu damai dengan mempertanyakan “damai apanya?" 12 komentar lainnya bersifat junk dan tidak sesuai dengan tema.

Posting lain yang terkait dengan tema kekerasan atas nama agama adalah posting yang berjudul "Lagi Kekerasan Atas Nama Agama." Dalam posting tersebut, Kaskuser dengan id vaniasistro mengomentari berita yang dimuat di detiknews.com mengenai harapan agar jangan sampai terjadi lagi kekerasan atas nama agama. ${ }^{34}$ Ia mengatakan:

"Yang membedakan manusia dengan binatang salah tiganya adalah akal, perbuatan dan hati nurani. Kalau manusia sudah tidak punya akal dan hati nurani, terus apa bedanya dengan binatang? Suatu kelompok akan hancur

\footnotetext{
${ }^{32}$ Tertulis dengan huruf tebal untuk memberikan penekanan pada kalimat.

${ }^{33}$ Karena pada dasarnya terdapat satu hal universal yang diterima oleh para penganut agama manapun (baik agama teistik maupun non teistik, agnostik ataupun ateis) yaitu bahwa manusia memiliki value serta martabat bawaan untuk dihormati dan menghormati, lihat: M. Mazzahim Mohideen, "Islam, Nonviolence, and Interfaith Relations," dalam Glend D. Paige, Chaiwat SathaAnand, dan Sarah Gilliatt (eds.), Islam and Nonviolence (Hawai'i: Center for Global Nonviolence, 2001), 123.

${ }^{34}$ Berita

selengkapnya

dapat

diakses

di

http://www.detiknews.com/read/2011/02/07/192334/1562057/10/jangan-sampai-terjadi-lagi-

kekerasan-atas-nama-agama
} 
dengan sendirinya bukan karena pengaruh luar tapi karena perilaku-perilaku anggotanya sendiri. Sudah banyak bukti gan. Berbelas kasihan, puasa, berbuat baik, membunuh dan menyiksa diperbolehkan dan dapat pahala?? Ajaran dari mana itu??????? WTF"35

Posting ini mendapatkan banyak komentar yang mayoritas bahkan seluruhnya menyatakan setuju untuk menghentikan kekerasan berdalih agama. Tapi permasalahan menjadi rumit ketika permasalahan penodaan agama yang akhirnya menimbulkan kekerasan berbenturan dengan masalah HAM (Hak Asasi Manusia). 37 orang menyatakan bahwa atas dasar apa pun, bagaiamanapun keyakinan keagamaannya, sesungguhnya merusak, bertindak anarkis hingga menghilangkan nyawa orang, adalah perbuatan yang tidak dapat diterima. Di antara yang berkomentar demikian adalah seorang Kaskus maniac dengan id fienka yang menulis dengan huruf tebal "ini bukan masalah sesat atau bukan, ini masalah nyawa seseorang." Komentar senada juga disampaikan oleh shokazamatsuri yang menulis "saya komen bukan sebagai orang beragama Islam, Kristen, Katolik, dll tapi saya komen sebagai warga negara Indonesia. Kalo mereka sesat, emang berarti kita manusia punya hak buat membunuh mereka?? Ajaran darimana itu ya?? Allah gak perlu dibela, karena dia Maha Kuasa kalo ada Tuhan yg dibela, berarti Dia gak Maha Kuasa lagi dong. Silahkan jawab sendiri."

Sementara itu, 11 orang berpendapat bahwa menjaga kesucian keyakinan kita adalah harga mati yang harus diperjuangkan, dan kekerasan hanya akibat dari penodaan yang pihak luar lakukan terhadap keyakinan kita. Terdapat beberapa yang sejalan dengan pandangan ini, di antaranya, adalah seorang Kaskus addict, Ibnu Seno, yang menulis dengan huruf tebal dan ukuran besar "HENTIKAN PENISTAAN AGAMA BERKEDOK HAM" ${ }^{36}$ Hal senada juga disampaikan oleh seorang Kaskus addict, u22y yang mengomentari kekerasan yang terjadi terhadap warga ahmadiyyah "Ahmadiyah emang udah sesat, mengakui ada Nabi lagi setelah Nabi Muhammad SAW dan mengutak-atik isi al-Quran. Wajar masyarakat resah, kerusuhan yang terjadi kemarin-kemarin adalah puncaknya."

Selain komentar seputar HAM dan penodaan agama tersebut, ada 5 orang yang berkomentar bingung dengan permasalahan ini. Mereka merasa fenomena benturan HAM dengan penodaan agama sesuatu hal yang sangat rumit. Dan 8

\footnotetext{
${ }^{35}$ Komentar senada juga diungkapkan oleh Alparslan Acikgenc yang mengatakan bahwa dasar psikologis fenomena permusuhan sesungguhnya merupakan unsur alami hewan, bukan manusia. Dalam hal ini, Acikgenc melihat bahwa di antara tujuan kedatangan Islam adalah untuk mengembalikan fitrah baik yang ada dalam diri manusia. Lihat: Alparslan Acikgenc, "An Evaluation of Violence from Islam's Perspective," ALTERNATIVES Turkish Journal of International Relations, vol. 1 no. 1 (2002).

${ }^{36}$ Tertulis dengan huruf kapital dan tebal untuk memberikan penekanan pada kalimat.
} 
orang mengomentari untuk mengajak berdamai. Menurut mereka, terlepas dari benturan tersebut, hal yang lebih penting adalah menjaga kedamaian di Indonesia ini.

\section{Sumbu Api Kekerasan Atas Nama Agama}

Seorang "aktivis Kaskus" yang memiliki ID Dazara memposting thread yang ia ambil dari portal berita online inilah.com yang memberitakan bahwa juru bicara Partai Demokrat, Ruhut Sitompul, menuding kekerasan berlatar belakang agama yang terjadi belakangan ini dampak dari tokoh-tokoh agama yang bermain politik. Dalam berita tersebut, dituliskan bahwa menurut Ruhut, bentrokan di Banten dan kerusuhan di Temanggung merupakan pembelajaran sangat penting bagi mereka yang mengaku sebagai tokoh agama. "Jangan bilang mereka tokoh lintas agama. Kalau masalah seperti ini tidak ditangani," jelasnya. Lebih jauh Ruhut mengatakan, tokoh-tokoh lintas agama sebenarnya tidak murni dan benar-benar mengurusi agama, mereka juga berpolitik. "Saya tahu isi perut mereka orang politik, saya tahu ada yang mencalonkan diri jadi menteri tapi nggak jadi menteri, mencalonkan jadi wapres gagal, jadi jangan mengatasnamakan agama," jelasnya. ${ }^{37}$

Thread yang dibuat oleh Dazara ini mengundang 92 komentar yang beragam, tetapi secara garis besar komentar dapat diklasifikan menjadi empat: pertama, komentar yang setuju bahwa akar permasalahan kekerasan at as nama agama di Indonesia berada pada ulama yang berpolitik sehingga ulama seharusnya tidak berpolitik atau dengan kata lain tidak perlu mencampur adukkan antara agama dan politik. Ada 13 komentar yang menyatakan setuju dengan hal ini. Diantaranya komentar seorang "Kaskus holic" Hackman yang mengatakan: "mending agama dan politik jangan disatukan. Bagaikan bensin dengan api" dan komentar rohmant yang mengatakan "yaaa...jangan begitulah masa agama dicampur adukkan Politik jadinya ya begini."

Kedua, komentar yang tidak setuju dengan pernyataan Ruhut Sitompul (selanjutnya disingkat RS) yang mengkambinghitamkan ulama atas fenomena kekerasan yang terjadi di Indonesia. Apa yang diucapkan RS sesungguhnya hanyalah bentuk pengalihan isu belaka bahkan kejadian kekerasan tersebut sudah direkayasa sebelumnya agar menjatuhkan ulama. Ada 18 komentar yang termasuk dalam klasifikasi ini, contohnya komentar yang dikatakan seorang "Kaskus addict" Medummy "bau pengalihan isu makin kuat neeeh (ikon ngakak)."

${ }^{37}$ Berita selengkapnya dapat diakses di http://nasional.inilah.com/read/detail/1221522/pdkekerasan-agama-akibat-tokoh-agama-berpolitik 
Ketiga, komentar yang tidak setuju dengan pernyataan RS dan beranggapan sesungguhnya fenomena kekerasan atas nama agama yang terjadi di Indonesia adalah akibat kesalahan, ketidak tegasan dan ketidak mampuan pemerintah mengatur urusan keberagaman rakyatnya. 13 komentar menyatakan hal demikian. Seperti yang dikatakan Cerianay, seorang Kaskus addict yang menyatakan "karena rezim SBY yang di support sama PD secara politik, tidak tegas dalam bersikap," atau seperti komentar seorang Kaskus holic Shiningallspark "Inilah cermin ketidakmampuan pemerintah untuk menjamin warganya akan kebebasan dan kerukunan, dengan gampangnya mereka melempar permasalahan pada para toko agama yang kemarin mengkritik pemerintah. Para tokoh tidak hanya punya peranan mengurusi masalah umat semata, tapi ada fungsi pengingat bagi para umaro'."

Keempat, komentar yang berisi cacian kepada RS karena komentarnya yang dianggap tidak beres. Terdapat 22 komentar yang tergolong dalam jenis ini, diantaranya komentar yang diungkap oleh seorang "Kaskus addict" awanmendung "UUD tidak pernah melarang orang Indonesia untuk berserikat dan berkumpul, mengeluarkan pendapat alias berpolitik. Jadi Bang Ruhut telah menistakan UUD. Katanya ahli hukum" atau pendapat bangyons "Poltak raja minyak dari Medan lagi mengigau. Bangun bung poltak, sudah siang bung."

Selain empat kategori komentar di atas, jenis komentar kelima adalah komentar yang tidak ada hubungannya dengan kasus kekerasan atas nama agama, seperti komentar yang mempertanyakan siapa yang dimaksud oleh RS dalam pernyataannya tersebut, mendinginkan suasana forum, jokes dan lainlain.

Terdapat posting lain yang penulis kategorikan sebagai jenis posting tentang akar kekerasan atas nama agama yaitu posting yang ditulis oleh seorang newbie dengan id antikekerasan. Ia menulis dengan judul "agama provokator," sebagai berikut:

"Hampir disemua agama pasti ada provokatornya. Hindu, Budha dan Kristen menurut sejarahnya semua memiliki sisi kelam akibat ulah para provokator yang berjubah agama. Sebut saja "perang salib" yang dikumandangkan oleh para provokator agama Kristen di masa lalu. Ternyata perang itu hanya kedok agama untuk melakukan kejahatan. Hasilnya yang menderita ya semua orang termasuk penganut Kristen sendiri.

Tapi pengalaman itu telah menjadi pelajaran sangat berharga bagi pemeluk agama Kristen saat ini. Itulah mengapa pemeluk agama ini tidak lagi mudah terprovokasi. Bahkan ketika Amerika memprovokasi untuk melakukan perang atas kedok pembasmian teroris. Bahkan masyarakat kristen dan pemuka agama kristen ikut mengkritik dan menolak cara - cara seperti itu. Bahkan berbuah 
manis dengan disetujuinya penarikan pasukan Amerika dari Afganistan dan Irak secara bertahap.

Sekarang Islam juga sedang diuji kedewasaan pemeluknya dengan maraknya para provokator dari kalangan Islam garis keras yang ingin membuat chaos dan memanfaatkannya demi kepentingan mereka. Cara cara yang hampir sama dengan apa yg pernah dirasakan kaum Nasrani ratusan tahun yang lalu.

Semoga kaum Muslim sekalian juga bisa melewati masa ujian ini dengan baik. Menahan diri dan mengolah semua isu dengan benar adalah kuncinya agar provokasi sulit menembus agama Islam. Dari pengalaman agama lain, umat Islam harus berani mengatakan tidak pada kekerasan walau mereka menggunakan jubah dan takbir. Karena agama Islam adalah agama damai.

Hati hati denga para provokator ini. Mereka memakai jubah sama seperti dulu para provokator Kristen pada perang salib yang memakai jubah kebesarannya dengan logo salib didadanya tapi kelakuannya biadab dan lebih setan dari setan."

Terdapat 6 komentar untuk thread ini, semuanya menyatakan setuju dengan isi posting tersebut kecuali satu orang yang mengatakan tidak mau ikut campur.

Dari beberapa komentar Kaskuser di atas, dapat disimpulkan bahwa menurut para Kaskuser, terdapat tiga faktor penyebab terjadinya kekerasan at as nama agama (khususnya di Indonesia): ulama yang berpolitik, ketidak tegasan dan ketidak mampuan pemerintah mengatur urusan keberagaman rakyatnya, dan provokator.

Senada dengan para Kaskuser, hasil web survey yang penulis sebar di Facebook dan forum online juga menyatakan bahwa diantara penyebab terjadinya kekerasan atas nama agama adalah pemerintah (sebagaimana diakui oleh 16 responden). Menurut mereka, hal ini karena pejabat sering mempertontonkan tindakan yang tidak terpuji, tidak adanya ketegasan dalam membuat maupun menjalankan hukum, terlalu memihak kepada mayoritas, tidak adil, pemerintah tidak merepresentasikan rakyat, dan pemerintah lebih "membebek" kepada kebijakan Barat yang berideologi liberal dan kapitalis.

Masih berdasarkan hasil web survey, kekerasan atas nama agama juga disebabkan oleh para penganut agama (sebagaimana diakui oleh 52 responden). Sikap seenaknya menafsirkan ajaran agama, minimnya rasa kesadaran dan sikap toleransi, fanatisme sempit, mundurnya kualitas mental kedewasaan dan sumber daya manusia merupakan faktor-faktor pendukung terjadinya kekerasan atas nama agama di level para pemeluknya. Tidak hanya faktor para pemeluk agama, agama itu sendiri dianggap menjadi salah satu penyebab utama terjadinya kekerasan atas nama agama karena banyaknya ayat-ayat yang rancu (multi tafsir) dan harus diluruskan. Dalam hal ini, seorang mantan intelejen 
CIA yang juga seorang profesor bidang sejarah di Simon Fraser University , Graham E. Fuller menulis buku yang berjudul "A World Without Islam.” Buku yang menyoroti hubungan Islam (baca: Timur Tengah) dan Barat (baca: Amerika) ini menyimpulkan bahwa walaupun seandainya tidak pernah ada agama Islam di dunia ini, hubungan Timur Tengah dan Amerika sesungguhnya akan tidak jauh berbeda dengan apa yang terjadi saat ini. ${ }^{38}$ Terorisme, yang merupakan faktor utama penyulut kebencian Amerika terhadap Islam, sesungguhnya hanyalah buah dari penafsiran menyimpang ajaran-ajaran Islam bahkan Islam pun sesungguhnya tidak menghendaki hal tersebut.

Kekerasan atas nama agama, berdasarkan hasil web survey, juga disebabkan oleh media. Setidaknya terdapat empat orang responden mengatakan bahwa penyebab utama terjadinya kekerasan atas nama agama adalah media. Alasan pandangan ini, di antaranya adalah karena media adalah salah satu acuan dalam menilai suatu agama, dan ketergantungan masyarakat terhadap media yang menyebabkan tolak ukur kebenaran atas apa-apa yang ada di media dan karena media terlalu banyak menayangkan kekerasan.

Internet, dalam hal ini, merupakan media potensial untuk menyalurkan hasrat individu atau golongan yang merasa termarjinalkan. Melalui Internet mereka dapat dengan bebas menyebarkan opini dan pengaruh mereka. ${ }^{39}$ Sifat Internet yang terbuka untuk siapa pun ini tent unya tidak disia-siakan oleh para penganut Islam garis keras. ${ }^{40}$ Jika ditinjau dari sudut ilmu komunikasi, hal ini tent unya menambah dahsyat arus informasi-informasi radikal yang tanpa henti menyerang para pengguna media massa. Serangan arus deras informasi ini bukan tidak mungkin membentuk pola fikir seseorang dan memberikan stimulus untuk mengerjakan apa yang ada dalam pesan tersebut.

Terkait hal ini, penulis mempertanyakan seberapa besar pengaruh media (baik cetak maupun elektronik) terhadap kekerasan atas nama agama yang terjadi kepada para responden di dunia maya melalui web survey. Dari web survey ini terungkap bahwa menurut kebanyakan netizen Indonesia, media

\footnotetext{
${ }^{38}$ Graham E. Fuller, A World Without Islam (New York: Little, Brown and Company, 2010).

${ }^{39}$ Merlyna Lim, "Islamic Radicalism and Anti-Americanism in Indonesia: The Role of the Internet" diunduh online dari http://www.eastwestcenter.org/fileadmin/stored/pdfs/PS018.pdf pada tanggal 9 Oktober 2011.

${ }^{40}$ Peter Margulies mengatakan bahwa kelompok teroris kebanyakan menyebarkan ideologi mereka dengan menggunakan Internet, lihat: "The Clear and Present Internet: Terrorism, Cyberpsace, and The First Amendene," UCLA Journal of Law and Technology, dapat diakses di http://www.lawtechjournal.com/articles/2004/04_041207_margulies.pdf, begitu juga dengan Phyllis B. Gerstenfeld, Diana R. Grant dan Chau-Pu yang menyimpulkan bahwa Internet telah menjelma menjadi ladang subur dan alat paling ampuh bagi para ekstrimis untuk simpatisan di tingkat internasional, merekrut anggota dan saling berhubungan dengan kelompok-kelompok lainnya, lihat: Phyllis B. Gerstenfeld, Diana R. Grant, Chau-P Chiang, "Hate Online: A Content Analysis of Extrimist Internet Sites," Analysis of Social Issues and Public Policy, vol. 3, no. 1, (2003), p. 29-44.
} 
memang sangat berpengaruh. Setidaknya 50 orang menyatakan hal tersebut. Di antara alasannya adalah karena akses media menyentuh semua kalangan dengan cepat, media hanya memberikan berita mentah, media sudah menjadi pusat informasi utama saat ini, penyebaran informasi apapun sangat bergantung pada media, media terbiasa melebih-lebihkan informasi yang ada dan karena media sering ditunggangi pihak tertentu untuk kepentingan tertentu. Sementara itu, 8 orang menyatakan bahwa media tidaklah berpengaruh karena menurut mereka media tidak akan dapat mempengaruhi keimanan yang kuat dan utuh, media hanya memberitakan, dan belum ada media yang secara terang-terangan memprovokasi orang untuk berbuat kekerasan atas nama agama.

Dalam konteks efek media terhadap kekerasan, penulis mendapatkan hal lain yang tidak kalah menarik untuk dianalisa lebih lanjut, yaitu diskursus mengenai efek konten-konten kerekasan di media terhadap anak-anak dan remaja. Huesmann menyatakan konten-konten kekerasan yang ada di media, video game, ${ }^{41}$ telpon selular, dan Internet memberikan efek meningkatnya kecenderungan bersikap keras (baik jangka pendek maupun panjang) pada diri anak-anak. ${ }^{42}$ Berbeda dengan Huesmann, Hugh Tobin dalam "Is Facebook making our kids violent?" menyatakan bahwa sesungguhnya tidak ada bukti kuat keterkaitan aktivitas di Internet dengan perilaku kekerasan remaja. ${ }^{43}$ Menurutnya hal tersebut hanyalah bentuk keinginan media untuk membangkitkan moral panic di kalangan masyarakat. Meski apa yang dikemukakan Huesmann bisa berlaku dalam beberapa kasus, dalam konteks perdebatan ini, penulis cenderung sependapat dengan Tobin bahwa, remaja, berdasarkan data yang penulis himpun, justru menunjukkan pola fikir kritis dalam merespons fenomena kekerasan atas nama agama. ${ }^{44} \mathrm{Hal}$ ini terlihat dari

\footnotetext{
${ }^{41}$ Penelitian mengenai konten kekerasan yang ada di video game yang dilakukan oleh Williams dan Skoric ternyata tidak mendukung bahwa hal tersebut akan meningkatkan perilaku kekerasan di dunia nyata. Lihat: Dmitri Williams \& Marko Skoric, "Internet Fantasy Violence: A Test of Aggression in an Online Game," Communication Monographs, vol. 72, no.2 (June, 2005), p. 217-233.

${ }^{42}$ L. Rowell Huesmann, review article "The Impact of Electronic Media Violence: Scientific Theory and Research," Journal of Adolescent Health 41 (2007) S6-S13. Konten-konten kekerasan di media (baik cetak maupun elektronik terbukti meningkatkan agresifitas dan kecenderungan bersikap keras bagi anak-anak, khususnya anak remaja, lihat: Craig A. Anderson, Leonard Berkowitz, et.al, "The Influence of Media Violence on Youth," Psychological Science in The Public Interest, vol. 4, no. 3, December (2003).

${ }^{43}$ Hugh Tobin, "Is Facebook making our kids violent," diakses online dari http://www.ipa.org.au/publications/1390/is-Facebook-making-our-kids-violent- pada 9 Oktober 2011.

${ }^{44}$ Survei yang dilakukan oleh Pew Research Center for the People \& the Press yang dilakukan pada 22 Februari hingga 1 Maret 2011 mengungkap bahwa kebanyakan anak muda menolak ide bahwa Islam - di antara agama-agama lain — adalah agama yang paling mendukung kekerasan. The Pew Research Center for the People \& The Press, "Conituing Divide in Views of Islam and Violence," diunduh online dari http://www.people-press.org/files/2011/03/714.pdf
} 
bagaimana mereka menjawab dan memberikan alasan atas pertanyaan mengenai akar kekerasan atas nama agama, solusi dan bagaimana pengaruh media terhadap fenomena kekerasan yang terjadi (lihat tabel 1)

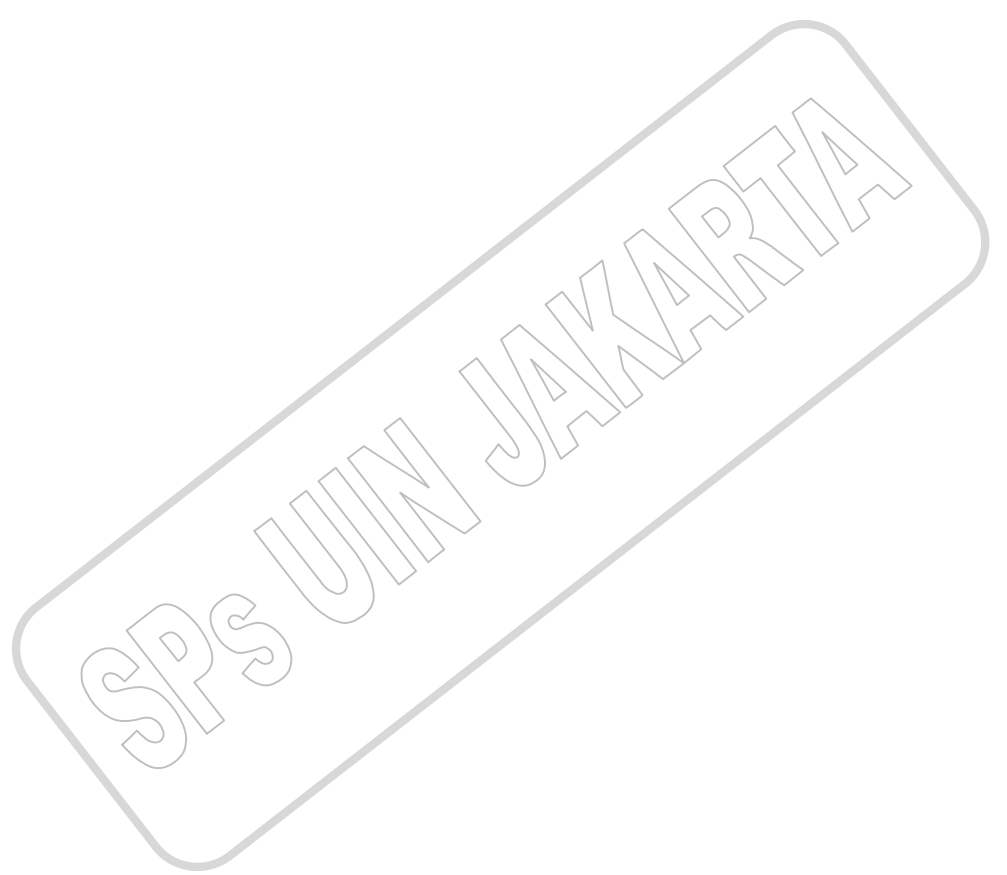




\begin{tabular}{|c|c|c|c|c|}
\hline $\begin{array}{l}\text { Penyebab } \\
\text { utama } \\
\text { terjadinya } \\
\text { kekerasan atas } \\
\text { nama agama? }\end{array}$ & Alasannya? & $\begin{array}{l}\text { Terus apa dong solusinya agar } \\
\text { tidak terjadi lagi kekerasan atas } \\
\text { nama agama? }\end{array}$ & \begin{tabular}{l}
\multicolumn{1}{c}{ Seberapa } \\
besar pengaruh \\
media (baik cetak \\
maupun elektronik) \\
terhadap kekerasan \\
atas nama agama \\
yang terjadi?
\end{tabular} & Alasannya? \\
\hline $\begin{array}{l}\text { Penganut } \\
\text { agama }\end{array}$ & Yang bejat ya orangnya & $\begin{array}{l}\text { Pemerintah harus tegas, media } \\
\text { wajib memfilter berita dan } \\
\text { netral, tidak malah memancing- } \\
\text { mancing dengan berita } \\
\text { kontroversial yang bikin rusak } \\
\text { negara }\end{array}$ & Sangat berpengaruh & $\begin{array}{l}\text { Banyak media dipake } \\
\text { politik }\end{array}$ \\
\hline $\begin{array}{l}\text { Penganut } \\
\text { agama }\end{array}$ & $\begin{array}{l}\text { Saya yakin semua agama } \\
\text { mengajarkan kasih }+ \\
\text { kebaikan. Yang menjadi } \\
\text { masalah adalah persepsi orang } \\
\text { tersebut untuk } \\
\text { mempertahankan atau } \\
\text { membela } \\
\text { keyakinannya.Sehingga } \\
\text { kekerasan pun dilegalkan atas }\end{array}$ & $\begin{array}{l}\text { Memperdalam agama itu sendiri } \\
\text { agar tidak salah kaprah }+ \\
\text { bimbingan dari para pemuka } \\
\text { agama. }\end{array}$ & Sangat berpengaruh & $\begin{array}{l}\text { Media dapat menjadi } \\
\text { pedang bermata dua. Bisa } \\
\text { memberi suatu informasi } \\
\text { atau bisa juga } \\
\text { menginspirasi seseorang } \\
\text { utk melakukan suatu } \\
\text { tindakan yg diberitakan } \\
\text { di media. }\end{array}$ \\
\hline
\end{tabular}




\begin{tabular}{|c|c|c|c|c|}
\hline & nama agama. & & & \\
\hline Ajakan orang & $\begin{array}{l}\text { Biasanya di ajak oleh } \\
\text { komunitas-komunitas "freak" } \\
\text { seperti didoktrin pikirannya } \\
\text { agar menjadi teroris, dengan } \\
\text { prinsip masuk surga. WTF? } \\
\text { ya itu ajaran yang salah dalam } \\
\text { agama saya. }\end{array}$ & $\begin{array}{l}\text { memahami dan mendalami } \\
\text { agama dengan benar. jangan } \\
\text { sampai ikut dengan jaringan- } \\
\text { jaringan teroris dan didoktrin } \\
\text { pikirannya }\end{array}$ & Berpengaruh & bisa terprovokasi \\
\hline $\begin{array}{l}\text { Banyaknya } \\
\text { ideologi yang } \\
\text { salah }\end{array}$ & $\begin{array}{l}\text { Agama tidak pernah salah } \\
\text { dalam suatu tindakan } \\
\text { kriminal, semua kembali ke } \\
\text { manusianya. } \\
\text { Dan orang-orang yang telah } \\
\text { melakukan kekerasan atas } \\
\text { dasar agama, hanya salah } \\
\text { dalam mempercayai orang } \\
\text { dalam ketidaktahuan yang } \\
\text { mereka alami, sehingga } \\
\text { doktrin dan idelogi menjadi } \\
\text { peran yang sangat penting. }\end{array}$ & $\begin{array}{l}\text { pembetulan ideologi yang salah } \\
\text { menjadi benar dan dilakukan } \\
\text { oleh media elektronik. Dari } \\
\text { sesuatu yang salah menjadi } \\
\text { benar oleh sumber yang telah } \\
\text { memberikan ideologi yang salah } \\
\text { tersebut. }\end{array}$ & Tidak berpengaruh & Nonsense \\
\hline
\end{tabular}




\begin{tabular}{|c|c|c|c|c|}
\hline $\begin{array}{l}\text { Penganut } \\
\text { agama }\end{array}$ & $\begin{array}{l}\text { ya mungkin mereka } \\
\text { menganggap bahwa agama } \\
\text { mereka adalah agama yang } \\
\text { lebih baik dari agama lainnya. }\end{array}$ & kerahkan Petrus & Berpengaruh & saya juga tidak tahu \\
\hline Pemerintah & $\begin{array}{l}\text { pemerintah gan, coba kalau } \\
\text { pemerintahanya adil, dekat } \\
\text { sama rakyat, enggak korup, } \\
\text { dan rakyatnya jadi sejahtera, } \\
\text { gue pikir gak ada yang } \\
\text { namanya kekerasan atas nama } \\
\text { agama. }\end{array}$ & $\begin{array}{l}\text { pemerintah harus kerja yang } \\
\text { bener, paling enggak bikin } \\
\text { rakyat sejahtera deh, masa iya } \\
\text { rakyat udah pada sejahtera } \\
\text { hidupnya, diperlakukan dengan } \\
\text { adil, masih mau rusuh? pake } \\
\text { bawa-bawa nama agama lagi... } \\
\text { kita juga sebagai umat } \\
\text { beragama harus menjalankan } \\
\text { ibadah yang benar, } \\
\text { meningkatkan kualitas iman, } \\
\text { sehingga tidak mudah } \\
\text { melakukan tindakan-tindakan } \\
\text { anarkis. Kan kalo dipikir-pikir } \\
\text { kondisi aman tentram antar } \\
\text { umat beragama itu indah banget } \\
\text { ya...mudah-mudahan negara } \\
\text { kita bisa aman, tentram, } \\
\text { pemerintahnya jujur, adil, dan }\end{array}$ & & $\begin{array}{l}\text { karena masyarakat } \\
\text { melihat peristiwa dari } \\
\text { media gan. Kadang- } \\
\text { kadang media juga } \\
\text { melebih-lebihkan atau } \\
\text { memelintir berita yang } \\
\text { sesungguhnya, yang bisa } \\
\text { jadi akan membuat } \\
\text { banyak orang } \\
\text { terprovokasi.... } \\
\text { maaf kalau bahasanya } \\
\text { salah :) }\end{array}$ \\
\hline
\end{tabular}

222 | INDO-ISLAMIKA, Volume 1, Nomor 2, 2012/1433 


\begin{tabular}{|c|c|c|c|c|}
\hline & & amanah. & & \\
\hline $\begin{array}{l}\text { OKNUM dari } \\
\text { salah satu } \\
\text { agama }\end{array}$ & $\begin{array}{l}\text { kalau menurut ane enggak ada } \\
\text { agama yang mengajarkan } \\
\text { keburukan. Brati oknum dari } \\
\text { salah satu agama itu lah } \\
\text { penyebabnya. }\end{array}$ & $\begin{array}{l}\text { kalau menurut ane masing } \\
\text { masing aja toh negara kita } \\
\text { bukan negara agama. } \\
\text { dan kalau bisa saling } \\
\text { "berpegangan" karena kita } \\
\text { bhineka tunggal ika }\end{array}$ & Berpengaruh & $\begin{array}{l}\text { di jaman globalisasi } \\
\text { begini media akan } \\
\text { menjadi media kekerasan } \\
\text { agama. }\end{array}$ \\
\hline $\begin{array}{l}\text { pihak-pihak } \\
\text { tertentu yang } \\
\text { ingin mencari } \\
\text { sensasi dimana } \\
\text { mencangkup } \\
\text { penganut } \\
\text { agama dan } \\
\text { mungkin media }\end{array}$ & $\begin{array}{l}\text { Karena segala sesuatunya } \\
\text { pasti ada yang namanya } \\
\text { campur tangan seorang } \\
\text { provokator, baik dia yang } \\
\text { menganut agama itu ataupun } \\
\text { pihak luar yang menginignkan } \\
\text { keributan. Tidak jarang } \\
\text { seorang penganut yang belum } \\
\text { memperdalam ajaran } \\
\text { agamanya sendiri dan hanya } \\
\text { ikut-ikutan "sekelompok } \\
\text { besar orang" tanpa tahu } \\
\text { kebenaran yang terjadi dan } \\
\text { apa tujuannya. }\end{array}$ & $\begin{array}{l}\text { untuk para pemuka agama } \\
\text { (pasti ada dong di setiap } \\
\text { kelompok masyarakat), } \\
\text { rangkullah para masyarakatnya } \\
\text { dengan ajaran-ajaran yang benar } \\
\text { (bukannnya jadi provokator), } \\
\text { menjelaskan mana yang baik } \\
\text { dan mana yang buruk agar } \\
\text { mereka tidak salah langkah dan } \\
\text { hanya ikut-ikutan. }\end{array}$ & Berpengaruh & $\begin{array}{l}\text { Karena kadang media } \\
\text { terlalu melebih-lebihkan } \\
\text { sebuah berita yang } \\
\text { dimana hal itu dapat } \\
\text { memancing yang } \\
\text { namanya fitnah atau } \\
\text { kesalahpahaman. }\end{array}$ \\
\hline
\end{tabular}

\section{Tabel 1.}

Respons responden berumur 15-20 mengenai akar kekerasan atas nama agama, solusi dan bagaimana pengaruh media 


\section{Jalan Keluar Kasus Kekerasan atas nama Agama}

Di antara posting yang terkumpul, penulis menemukan satu posting yang membahas solusi yang mungkin diambil agar tidak terjadi lagi kekerasan atas nama agama di Indonesia. Posting yang ditulis oleh seorang Kaskus addict dengan id "penjahatsukses" berjudul "Mengapa kekerasan berlandaskan agama sulit dihentikan?? [yang peduli Indonesia MASUK]." Dalam postingnya tersebut, "penjahatsukses" mengomentari fenomena kekerasan atas nama agama yang terjadi di Banten, Temanggung dan Pasuruan. Menurutnya terdapat dua alasan mengapa hal itu bisa terjadi. Pertama adalah doktrin agama yang disalah artikan sehingga memunculkan sebuah kebencian dan akhirnya menyebabkan terjadinya kekerasan atas nama agama, dan kedua adalah alasan historis. Menurutnya, solusi untuk hal ini adalah upaya meningkatkan pemahaman para pemeluk agama terhadap ajaran-ajaran keagamaan yang dianutnya.

Posting ini mendapatkan 20 komentar. Empat di antaranya memberikan solusi yaitu, dengan cara lebih meningkatkan pemahaman terhadap ajaran masing-masing dan menambah ilmu pengetahuan. Dalam hal ini seorang Kaskuser menyarankan untuk juga mempelajari ajaran-ajaran agama orang lain untuk dapat lebih memahami. Satu orang Kaskuser memberikan solusi untuk bisa bersikap dingin dan berkepala dingin terhadap isu-isu sensitif empat orang Kaskuser lainnya berpendapat bahwa untuk menyelesaikan masalah kekerasan atas nama agama ini, Indonesia membutuhkan pemerintah dan pemerintahan yang netral dan tegas. Sedangkan 11 komentar lainnya justru kebingungan, dan tidak memiliki ide karena fenomena ini terlalu ruwet.

Kasus kekerasan atas nama agama (khususnya di Indonesia) merupakan fenomena yang harus dicarikan solusinya. Dalam hal ini, secara spesifik penulis menanyakan pendapat para netizen bagaimana mencegah terjadinya kekerasan atas nama agama di Indonesia melalui web survey. Menurut mereka, setidaknya terdapat tiga aspek yang perlu dibenahi, yaitu pemerintah, pemeluk agama, dan pekerja media. Pemerintah dan semua aparatnya harus tegas dalam membuat dan menegakkan hukum. ${ }^{45}$ Mereka harus bersikap netral, adil, dan tidak berburuk sangka terhadap agama tertentu. Mereka juga harus memahami agama dengan baik, bersinegergi dengan para pemuka agama, memfasilitasi dan mengusahakan peningkatan SDM masyarakat serta mensejahterakan rakyat.

Terkait dengan unsur pemeluk agama, setiap pemeluk agama diharapkan untuk memperdalam pengetahuan agamanya masing-masing dan

\footnotetext{
${ }^{45}$ Banyak hal yang harus dilakukan dalam hal ini, di antara hal paling esensial yang harus diupayakan oleh pemerintah, terkhusus presiden, untuk menghadapi gerakan-gerakan terorisme adalah memperkuat aspek keamanan nasional. Lihat: Zachary Abuza, Political Islam and Violence in Indonesia (New York: Routledge, 2007), 104.
} 
menerapkannya, tidak mudah terprovokasi, menumbuhkan sikap toleransi, bersikap open minded, melakukan introspeksi diri, memonitor diri dan keluarganya dari benih-benih kekerasan yang datang dari luar, bijaksana dalam menerima informasi, dan melakukan dialog. Para pekerja media juga diharapkan dapat bekerja dengan amanah dan seimbang dalam menyampaikan informasi dan patuh terhadap etika jurnalistik.

\section{Meninjau Ulang Efek Media Massa}

Dalam konteks kajian komunikasi, respons merupakan hal yang sangat penting untuk mengetahui efektivitas komunikasi yang sedang berlangsung. ${ }^{46}$ Karena dari respons inilah kita dapat mengetahui efek apa yang timbul pada diri komunikan. Dan efek itu sendiri merupakan tujuan utama dari sebuah proses komunikasi. ${ }^{47}$ Beragam teori komunikasi bermunculan menjelaskan bagaimana individu merespons pesan yang ia terima; diantaranya teori S-O-R (Stimulus-Organism-Responses) yang menjelaskan bahwa pesan tidak serta merta akan menghasilkan respons. Organisme, dalam hal ini komunikan, akan terlebih dahulu mengolah pesan yang diterimanya dan tentunya pesan yang disampaikan tersebut mungkin diterima dan ditolak. Teori ini menekankan signifikansi peran yang dimiliki komunikan dalam mengolah pesan.

Berbeda dengan teori S-O-R yang menekankan peran signifikan yang dimiliki oleh komunikan, dalam komunikasi massa dikenal teori peluru yang justru tidak melihat kekuatan apapun pada komunikan. Disebut teori peluru karena komunikan dianggap secara pasif menerima berondongan pesan-pesan komunikasi. Bila kita menggunakan komunikator yang tepat, pesan yang baik, atau media yang benar, komunikan dapat diarahkan sekehendak kita. Teori ini juga dikenal dengan teori jarum hipodermik. Teori ini mempunyai asumsi bahwa komponen-komponen komunikasi (komunikator, pesan, media) amat perkasa dalam mempengaruhi komunikan. ${ }^{48}$ Disebut model jarum hipodermik karena dalam model ini dikesankan seakan-akan komunikasi "disuntikkan" langsung ke dalam jiwa komunikan.

Sementara itu Raymond Bauer menyatakan bahwa khalayak merupakan sasaran yang tidak pasif. Mereka cenderung "bandel" (stubborn), ${ }^{49}$ dan secara

\footnotetext{
${ }^{46}$ Arvind Kumar, Encyclopedia of Mass Media and Communication, (New Delhi: Anmol Publication PVT. LTD., 1998) vol. 2, 149, Campbell dan Hapler, Dimensions in Communication (California: Wadsworth Publishing Company, 1969), 43.

${ }^{47}$ John Vivian, Teori Komunikasi Massa, alih bahasa: Tri Wibowo B.S (Jakarta: Kencana, 2008), 464.

${ }^{48}$ Jalaluddin Rakhmat, Metode Penelitian Komunikasi (Bandung: Penerbit Remadja Karya, 1989), 83.

${ }^{49}$ Disarikan dari Onong Uchjana Effendy, Ilmu, Teori dan Filsafat Komunikasi (Bandung: Penerbit PT. Citra Aditya Bakti, 2003), 265.
} 
aktif mereka mencari yang diinginkan dari media massa. Jika mereka telah menemukannya, mereka kemudian melakukan interpretasi sesuai dengan predisposisi dan kebutuhannya.

Menarik untuk dicatat bahwa sebuah teori baru yaitu teori uses and gratification diperkenalkan. Teori ini mengklaim bahwa media tidak melakukan sesuatu pada seseorang.Individulah yang melakukan sesuatu tersebut melalui media. ${ }^{50}$ Dengan kata lain, pengaruh media terbatas pada apa yang seseorang perkenankan. Pendekatan ini berawal dari pemikiran bahwa setiap individu adalah adalah seorang selektor aktif dari media komunikasi, sudut pandang ini berbeda dari teori peluru. Setali tiga uang dengan teori uses and gratification, Lee Thayer, ${ }^{51}$ Rene-Jean Ravault, Stuart Hall, ${ }^{52}$ Katz and Liebes, ${ }^{53}$ Ien Ang, ${ }^{54}$ begitu juga dengan Andi Faisal Bakti ${ }^{55}$ menyodorkan "teori resepsi aktif" (active-recipient theory) yang meyakini bahwa media massa tidaklah sehebat seperti yang dibayangkan banyak kalangan. Menurut mereka, para penerima pesan media (receiver) tidaklah pasif. Sebailknya mereka aktif, dan bahkan dapat memberikan reaksi berbalik sebagaimana dijelaskan oleh "teori boomerang" (boomerang effects theory). "T6 Teori resepsi-aktif ini meyakini bahwa sesungguhnya para receiver bukanlah orang-orang yang pasif ketika menerima pesan.

Jika kita mensinergikan beberapa teori di atas dengan hasil temuan penelitian ini, terlihat jelas bahwa hasil temuan penelitian ini mengkonfirmasi kebenaran teori S-O-R dan teori Resepsi Aktif (active-recipient theory) di mana kita melihat bahwa penerima pesan (receiver) dengan aktif memahami dan memaknai segala informasi. Originator bisa saja menciptakan "data-data"; tetapi receivertah yang menciptakan makna dari data-data tersebut bagi dirinya. Hal ini terlihat jelas dari komentar Kaskuser dan "fesbuker" (sebutan bagi mereka yang mempunyai akun Facebook) dalam menyikapi postingposting terkait fenomena kekerasan atas nama agama yang terjadi di Indonesia.

\footnotetext{
${ }^{50}$ Elihu Katz, Jay Blumler, and Michael Gurevitc, "Uses of Mass Communication by the Individual," dalam Mass Communication Research: Major Issues and Future Directions, eds. W. P. Davidson and F. Yu (New York: Praeger, 1974), 11-35.

${ }^{51}$ Lee Thayer, Communication and Communication Systems in Organization, Management, and Interpersonal Relations (Homewood, Illinois: Richard D. Irwin, INC., 1968).

${ }^{52}$ Stuart Hall, "Encoding/ decoding", dalam Culture, Media, Language, eds. Stuart Hall dll (New York: Routledge, 1980).

${ }^{53}$ Katz, E. And T. Liebes, "Mutual Aid in the Decoding of Dallas: Preliminary Notes from a Cross-Cultural Study." dalam P. Drummond and R. Paterson (eds.), Television in Transition (London: BFI Books, 1986), 187-280.

${ }^{54}$ Ien Ang, "The Nature of the Audience." Dalam J. Downing et al. (eds.), Questioning the Media (Newbury Park: Sage, 1990), 155-65.

${ }^{55}$ Andi Faisal Bakti, Communication and Family Planning in Islam in Indonesia: South Sulawesi Muslim Perceptions of A Global Development Program (Jakarta: INIS, 2004).

${ }^{56}$ Andi Faisal Bakti, Communication and Family Planning, 108, 113-117.
} 
Gempuran pesan-pesan dan informasi kekerasan at as nama agama yang mereka terima dari media ternyata tidak lantas membuat mereka setuju dengan kekerasan atau bahkan turut melakukan kekerasan. Hal ini membantah hasil penelitian Dutta-Bergman yang menyimpulkan bahwa orang-orang yang berpartisipasi dalam memposting dan membaca tentang kekerasan di dunia maya cenderung berpartisipasi dalam aksi kekerasan di dunia nyata. ${ }^{57}$

Di saat yang sama, hasil penelitian ini juga mengkonfirmasi kebenaran teori Uses and Gratification di_mana individu tidak dengan pasrah menerima terpaan arus informasi, tetapi ia dengan aktif memilah dan memilih informasi yang ia terima untuk memenuhi kebutuhannya. Hal ini terlihat jelas dari jenis junk (respons yang secara eksplisit mengyatakan tidak tertarik dan respons yang tidak ada hubungannya dengan posting) yang berjumlah 56 atau 18\% dari total respons yang ada.

Dalam konteks kajian ilmu dakwah, keberagaman respons, sikap kritis, serta antusias Kaskuser dan Fesbuker dalam menanggapi isu kekerasan atas nama agama ini merupakan fenomena kebangkitan mad'u (para konsumen dakwah) ${ }^{58}$ yang berimplikasi positif terhadap kelangsungan keberagamaan di Indonesia. Para konsumen dakwah (para penganut agama, khususnya Islam) mampu dan secara aktif mencerna isu-isu sensitif yang berkaitan dengan permasalahan agamanya tanpa harus terpengaruh oleh pihak-pihak yang menyebarkan isu tersebut.

\section{Penutup}

Penulis sepakat bahwa fenomena eksteremisme agama tidak terjadi dalam situasi vakum. ${ }^{59}$ Banyak hal yang melatar belakangi berbagai tindak kekerasan berdalih agama. Dalam hal ini kita harus mampu secara jernih melacak api yang menimbulkan asap kekerasan tersebut; faktor politik kah? ${ }^{60}$ Atau memang tafsiran-tafsiran radikal terhadap ayat-ayat kitab suci? ${ }^{61}$ Hasil penelitian ini membuktikan efektifitas forum-forum di dunia maya, khususnya Kaskus dan

\footnotetext{
${ }^{57}$ Mohan J. Dutta-Bergman, “Community Participation and Internet Use after September 2011: Complementarity in Channeel Consumption," Journal of Coputer Mediated Communication 11 (2006) 496-484.

${ }^{58}$ Fazlul Rahman, Matinya Sang Dai: Otonomisasi Pesan-Pesan Keagamaan di Dunia Maya (Jakarta: Penerbit LSIP, 2011).

${ }^{59}$ Bahtiar Effendy dan Mun'im A. Sirri, "Ekstermisme Islam: Bukan Sekedar Persoalan Teologis Atau Penafsiran Keagamaan," dalam Bahtiar Effendy dan Soetrisno Hadi (ed.), Agama dan Radikalisme di Indonesia (Jakarta: Penerbit NUQTAH, 2007), 36.

${ }^{60}$ Mark Sedgwick, "Al-Qaeda and the Nature of Religious Terrorism," Terrorism and Political Violence, vol. 16, no. 4 (winter 2004), pp. 795-814.

${ }^{61}$ Amritha Venkatraman, "Religious Basis for Islamic Terrorism: The Quran and Its Interpretations" Studies in Conflict \& Terorism, Vol. 30 Issue 3, pp. 229-248. Routledge-Taylor and Francis Group, 2007.
} 
Facebook, untuk menjadi wadah penyalur aspirasi dan mencari solusi terhadap benang kusut kekerasan atas nama agama.

Untuk masa-masa yang akan datang, penanganan penyebaran informasi secara sistematis dan menyeluruh. Tidak setengah-setengah. Dari berbagai pihak; baik pemerintah, pekerja media, maupun setiap individu. Merupakan hal paling urgen bagi umat Islam $^{62}$ dan seluruh umat manusia khususnya di Indonesia untuk dapat mengantarkan masyarakat Indonesia menjadi masyarakat yang lebih berperadaban.

\section{Daftar Pustaka}

Abdullah, Rasha A. "Islam, Jihad, and Terrorism in Post-9/11 Arabic Discussion Boards." Journal of Computer Mediated Communication 12 (2007): 1063-1081.

Abuza, Zachary. Political Islam and Violence in Indonesia. New York: Routledge, 2007.

Acikgenc, Alparslan. "An Evaluation of Violence from Islam's Perspective," ALTERNATIVES Turkish Journal of International Relations, vol. 1 no. 1 (2002).

Anderson, Craig A. Leonard Berkowitz, et.al, "The Influence of Media Violence on Youth." Psychological Science in The Public Interest, vol. 4, no. 3, December (2003).

Ang, Ien. "The Nature of the Audience." Dalam J. Downing et al. (eds.), Questioning the Media. Newbury Park: Sage, 1990.

Azra, Azyumardi. Konteks Berteologi di Indonesia. Jakarta: Penerbit PARAMADINA, 1999.

Bakti, Andi Faisal. Communication and Family Planning in Islam in Indonesia: South Sulawesi Muslim Perceptions of A Global Development Program. Jakarta: INIS, 2004.

Bergman, Mohan J. Dutta. "Community Participation and Internet Use after September 2011: Complementarity in Channeel Consumption.” Journal of Coputer Mediated Communication 11 (2006) 496-484.

Bruinessen, Martin van. "Genealogies of Islamic Radicalism in post-Suharto Indonesia." South East Asia Research vol. 10, no.2 (2002).

Bungin, M. Burhan. Sosiologi Komunikasi; Teori, Paradigma, dan Diskursus Teknologi Komunikasi di Masyarakat. Jakarta: Prenada Media Group, 2006.

${ }^{62}$ Azyumardi Azra, Konteks Berteologi di Indonesia (Jakarta: Penerbit PARAMADINA, 1999), 209. 
Campbell dan Hapler. Dimensions in Communication. California: Wadsworth Publishing Company, 1969.

Cavanagh, Allison. "Behavior in Public?: Ethics in Online Ethnography." Cybersociology 6, 2 (1999).

Cindy C Bombs dan Martin Slann. Encyclopedia of Terrorism. New York: Fact on File, Inc. An imprint of Infobase Publishing, 2007.

Effendy, Bahtiar dan Mun'im A. Sirri. "Ekstermisme Islam: Bukan Sekedar Persoalan Teologis Atau Penafsiran Keagamaan.” Dalam Bahtiar Effendy dan Soetrisno Hadi (ed.), Agama dan Radikalisme di Indonesia. Jakarta: Penerbit NUQTAH, 2007.

Effendy, Onong Uchjana. Ilmu, Teori dan Filsafat Komunikasi. Bandung: Penerbit PT. Citra Aditya Bakti, 2003.

Eichhorn, Kate. "Sites Unseen: Ethnographic Research in a Textual Community." Qualitative Studies in Education 14, 4 (2001): 565-78.

Fuller, Graham E. A World Without Islam. New York; Little, Brown and Company, 2010.

Hall, Stuart. "Encoding/decoding." Dalam Culture, Media, Language, eds. Stuart Hall dll. New York: Routledge, 1980.

Hine, Christine. Virtual ethnography. London: Thousand Oaks \& New Delhi: Sage, 2000.

Katz, E. And T. Liebes. "Mutual Aid in the Decoding of Dallas: Preliminary Notes from a Cross-Cultural Study." Dalam P. Drummond and R. Paterson (eds.), Television in Transition. London: BFI Books, 1986.

------, Jay Blumler, and Michael Gurevitc. "Uses of Mass Communication by the Individual." Dalam Mass Communication Research: Major Issues and Future Directions, eds. W. P. Davidson and F. Yu. New York: Praeger, 1974.

Kozinets, Robert V. Netnography: Doing Ethnographic Research Online. London: Sage Publications Inc., 2010.

Kumar, Arvind. Encyclopedia of Mass Media and Communication. New Delhi: Anmol Publication PVT. LTD., 1998. Vol. 2, 149.

Kuntsman, Adi. "Cyberethnography as Home Work." Anthropology Matters Journal 6, 2 (2004).

Makruf, Djamhari. "Radikalisme Islam di Indonesia: Fenomena Sesaat?" Dalam Bahtiar Effendy dan Soetrisno Hadi (ed.), Agama dan Radikalisme di Indonesia. Jakarta: Penerbit NUQTAH, 2007.

Markham, Annette. "Reconsidering self and other: the methods, politics, and ethics of representation in online ethnography." Dalam Handbook of 
qualitative research, ed. N.K. Denzin dan Y.S. Lincoln. Thousand Oaks: Sage, 2004.

Mohideen, M. Mazzahim. "Islam, Nonviolence, and Interfaith Relations." Dalam Glend D. Paige, Chaiwat Satha-Anand, dan Sarah Gilliatt (eds.), Islam and Nonviolence. Hawai' i: Center for Global Nonviolence, 2001.

Pallmeyer, Jack Nelson. Is Religion Killing Us? Violence in the Bible and the Quran. New York: The Continuum International Publishing Group, 2003.

Rahman, Fazlul. Matinya Sang Dai: Otonomisasi Pesan-Pesan Keagamaan di Dunia Maya. Jakarta: Penerbit LSIP, 2011.

Rakhmat, Jalaluddin. Metode Penelitian Komunikasi. Bandung: Penerbit Remadja Karya, 1989.

Sedgwick, Mark. "Al-Qaeda and the Nature of Religious Terrorism." Terrorism and Political Violence, vol. 16, no. 4 (winter 2004), pp. 795-814.

Thayer, Lee. Communication and Communication Systems in Organization, Management, and Interpersonal Relations. Homewood, Illinois: Richard D. Irwin, INC., 1968.

The Pew Research Center for the People \& The Press. "Conituing Divide in Views of Islam and Violence." Diunduh online dari http://www.peoplepress.org/files/2011/03/714.pdf

The Wahid Institute. "Laporan Kebebasan Beragama/Berkeyakinan dan Toleransi 2010." Diunduh online dari http://wahidinstitute.org/files/ docs/FULL\%20REPORT-

ANNUAL\%20REPORT\%20WI\%202010.pdf

Venkatraman, Amritha. "Religious Basis for Islamic Terrorism: The Quran and Its Interpretations." Studies in Conflict \& Terorism, Vol. 30 Issue 3, pp. 229-248. Routledge-Taylor and Francis Group, 2007.

Vivian, John. Teori Komunikasi Massa, alih bahasa: Tri Wibowo B.S. Jakarta: Kencana, 2008.

Wallace, Patricia. The Pscychology of The Internet. Cambridge: Cambridge University Press, 1999.

Wen, Sayling. Future of the Media. Batam: Lucky Publishers, 2002.

Williams, Dmitri \& Marko Skoric. "Internet Fantasy Violence: A Test of Aggression in an Online Game." Communication Monographs, vol. 72, no.2 (June, 2005), p. 217-233.

Wittel, A. "Ethnography On the Move: From Field to Net to Internet." Forum: Qualitative Social Research 1(1) (2000, January).

http://www.detiknews.com/read/2011/02/12/110434/1569963/10/hasyimmuzadi-nilai-ahmadiyah-tidak-bisa-dibubarkan http://www.detiknews.com/read/2011/02/12/141818/1570047/10/azyumardiazra-skb-3-menteri-sebaiknya-dijadikan-uu?nd991103605 
http://www.Kaskus.us/show thread.php?t=7143285

http://arsip.gatra.com/artikel.php?pil=23\&id=147407

http://www.alexa.com/topsites/countries/ID

http://nasional.inilah.com/read/detail/1221522/pd-kekerasan-agama-akibattokoh-agama-berpolitik

http://www.detiknews.com/read/2011/02/07/192334/1562057/10/jangansampai-terjadi-lagi-kekerasan-atas-nama-agama

http://www.suarapembaruan.com/index.php?detail=News\&id=27044

http://www.eastwestcenter.org/fileadmin/stored/pdfs/PS018.pdf

http://teknologi.vivanews.com/news/read/187470-11-tahun--popularitas-

Kaskus-tak-terbendung

http://news.okezone.com/read/extend/2009/10/15/343/265886/woyla-terorismepertama-di-indonesia

http://www.kompas.com/lipsus072009/ledakanmegakuningan

http://www.crisisgroup.org/en/regions/asia/south-east-asia/indonesia/B114indonesia-christianisation-and-intolerance.aspx

http://www.mediaindonesia.com/read/2010/12/22/189965/92/14/Kekerasanterhadap-Kerukunan-Beragama-Naik-30-persen

http://www.tempointeraktif.com/hg/nasional/2001/06/24/brk,20010624$\underline{06, \mathrm{id} . \mathrm{html}}$

http://www.beritajatim.com/detailnews.php/6/Politik_\&_Pemerintahan/201010-26/81954/Angka_Kekerasan_Beragama_di_Jatim_Melonjak www.alexa.com/siteinfo/Kaskus.us 